\title{
Settled Space. Evidence for Changes in Settlement Patterns of Northern Mesopotamia at the Advent and at the Turn of the Mittani Era
}

[...] interpretations of patterns of settlement and demographic trends are only as good as the quality of survey data retrieval. ${ }^{1}$

\section{Introduction}

Regional settlement studies are often based on the results of field surveys. Thus, in attempting to provide an overview of surveys concerning the second millennium BC in Northern Mesopotamia it is necessary to start with some methodological remarks, despite the fact that many archaeologists are familiar with at least some of the reservations that I will subsequently present. Recently, Tony Wilkinson ${ }^{2}$ and Arne Wossink 3 offered a similar evaluation, and therefore I will only comment on those issues that are the most relevant for the present study.

The most important and the most discussed point is the accuracy in identifying the occupation of a particular period and in determining the importance/size of the related settlement during the survey. As is well known, several factors may influence identifying the occupation as being from a particular period: later deposits can conceal earlier occupations; site erosion and soil aggravation lead to the physical loss of materials; smaller, flat sites are sometimes impossible to identify in the archaeological record; or the sample does not include the full range of pottery that is typical for a particular period.

The concealment of earlier sites by later settlement strata is a process that is not uniform and that depends on the settlement history of a particular area ${ }^{4}$. According to Wilkinson, 5 most of the sites located in the Khabur Area ceased to be occupied at the end of the third millennium. While the pre-Bronze Age levels are often obscured, later (i.e. second and first millennium BC) settlements are more easily identified. In a small number of sites that were occupied until the Islamic period Prehistoric, Bronze Age and Early Iron Age remains may be invisible.

* Institute of Prehistory, Adam Mickiewicz University of Poznań.

I Wilkinson 2000a, 22I.

2 Wilkinson 2000 .

3 Wossink 2009, 45-55.

4 Wossink 2009, 47.

5 Wilkinson 2000a, 229. 
Physical loss of sites due to erosion or soil aggravation is probably limited in northern Mesopotamia and appears to have occurred mainly during the $4^{\text {th }}$ millennium BC, ${ }^{6}$ thus rarely affecting later sites.

Archaeological surveys in Mesopotamia tend to concentrate on high, tell-like sites, making small or flat sites difficult to identify. Surveys only rarely include a full coverage of the area surveyed. This attitude has changed recently with the application of aerial and high resolution satellite imagery; pictures of this kind enable the identification of flat or even buried sites whose presence can be later verified in the field by surveys. Yet attempts to make a full coverage survey demonstrate that this method is also not fully effective.7

The chronological identification of the settlement periods of a given site is based on the ability to identify and date pottery sherds. The results of a survey depend on knowledge of the diagnostic pottery material for subsequent cultural periods. In the second millennium there are three cultural units: the Khabur Ware period (generally speaking, the first half of the second millennium $\mathrm{BC}$ ), the Mittani period (mid second millennium down to the I 4 th century BC) and the Middle Assyrian period (I4th - IIth century BC). While pottery belonging to this first cultural unit is easily recognizable because a significant percentage of sherds are decorated with characteristic painted patterns, the two other periods are much more difficult to identify. This difficulty has had a considerable influence on the results of earlier surveys. For instance, Diederik Meijer in his North-East Syria survey carried out in I976, divided the MBA period pottery into two groups, painted pottery (Khabur Ware) and plain pottery, but did not distinguish between Mittani and Middle Assyrian pottery, instead using a single designation: LBA period. ${ }^{8}$ Moreover, the published drawings of the LBA sherds included only five variants of bowls (though, of course, only a small sample of material was represented among the illustrations provided 9 ). As a result, his publication is of no use for my study. Wilkinson and Tucker, summing up their Northern Jazireh Survey, remarked that: "[the] degree of decline [of settlement during the LBA period] may be exaggerated by the lower visibility of the Middle Assyrian Pottery". ${ }^{\text {ro }}$ While they differentiated Mittani and Middle Assyrian material, the number of index fossils used was limited, which might have had a significant effect on their conclusions. For instance, only three pottery types were taken into account for the Mittani period: Nuzi Ware, stump bases, and fine painted goblets, ${ }^{\text {II }}$ while ignoring red band plates, which seem to be as typical of the Mittani period as Nuzi Ware, but much more popular.

6 E.g. Hole i997.

7 Wilkinson 1996 , I4.

8 Meijer 1986.

9 Cf. Meijer i986, $32 \mathrm{f}$.

Io Wilkinson - Tucker I995, 79 .

II Wilkinson - Tucker I995, 98. 


\section{The presentation of sources}

A considerable number of surveys have been conducted within the Jazireh; they are too numerous to present here a full analysis. ${ }^{\mathrm{I2}}$ Because a significant number of them are not fully published yet, three areas located within the Mittani Kingdom will be chosen for analysis: the Khabur Triangle area, the Balikh Valley and the Lower Khabur Valley.

The Upper Khabur Survey was conducted by Bertille Lyonnet in the early I990s. ${ }^{\text {I3 }}$ It covered the central part of the Khabur Triangle, but only around 60 sites of historic periods were surveyed, including mainly small and medium sized sites. ${ }^{\text {I4 }}$ On the one hand, it is not clear why some sites were chosen to be surveyed, while others were omitted.15 On the other, most of the visited sites were surveyed extensively, including in many cases small secondary sites located in the vicinity of the main, high mound. Another problem with the Khabur Survey is that the published summary of results does not differentiate between the Middle Assyrian and the Neo Assyrian period. This problem was only recently solved with the publication of the Middle and Neo Assyrian pottery collected during fieldwork. ${ }^{16}$ This also opens a new possibility to compare the settlement patterns from the Mittani period to Middle Assyrian times. Only a few of the surveyed sites were subsequently excavated (for instance, Tall Beydar and Tall Arbid). The results of the Upper Khabur Survey may be, to a certain extent, corroborated by smaller regional surveys. One of them has been undertaken in the vicinity of Tall Brak, ${ }^{17}$ the other around Tall Beidar. $^{18}$

The Balikh Drainage Survey was conducted by Peter M.M.G. Akkermans in I983 as part of the original research program at Tall Hammam at-Turkman. The results of this survey were presented in an unpublished PhD dissertation by Hans Curvers (I99I). Tony Wilkinson's subsequent survey of this area provided a means for verifying the results of the earlier research, especially on Iron Age sites. ${ }^{\text {I9 }}$ Last but not least, J. D. Lyon evaluated this area as well. ${ }^{20}$ It is important to note that a number of sites located in this area were excavated after they had been surveyed, thus providing an opportunity to cross-

\footnotetext{
I2 For the summaries cf. Wilkinson 2000a; Wossink 2009, 9I-99, fig. 5.I.

I3 Lyonnet 2000 .

I4 X. Faivre attempted an analysis of settlement pattern in his unpublished PhD thesis (I999; n.v.).

I5 B. Lyonnet, in her lecture presented during the same conference, explained that sites were chosen in a way providing uniform coverage of the whole area under the study (cf. Lyonnet, below).

I6 Anastasio 2007.

I7 Eidem - Warburton 1996.

I8 Wilkinson 200ob; Ur 2004.

I9 Wilkinson I998.

20 Lyon 2000.
} 
check the survey's accuracy. ${ }^{2 I}$ Wossink (2009) offered an additional assessment of the survey data.

The pottery from the Amsterdam University survey has been dated and evaluated according to pottery sequences from stratified deposits of the third and second millennium $\mathrm{BC}$ at Tall Hammam at-Turkman. ${ }^{22}$ The three periods under consideration here correspond to strata VIIA-C (MBA), VIIIA-B (Mittani) and VIIIC (Middle Assyrian) of this site. The survey seems to have had a very high chronological resolution (the MBA period is divided into three phases, and the Mittani period into two), but because periods were sometimes determined on the basis of a single sherd, these determinations may be exaggerated. In this situation, besides presenting sites according to the original chronological determinations, they will be synthesized on the period scale in order to obtain results comparable to other discussed areas. ${ }^{23}$

The Lower Khabur Valley was surveyed intensively during the I970s, first by a team of the TAVO project, headed by W. Röllig and H. Kühne (this survey covered the entire lower part of the valley, between Hasake and Khabur - Euphrates confluence). ${ }^{24}$ Y. Monchambert also surveyed this area before the announcement of the Hasake South Dam Salvage Project. ${ }^{25}$ Both surveys have never been fully published, but lists of sites and some details are available. Some period-orientated summaries of the TAVO survey have been attempted.$^{26} \mathrm{~A}$ considerable number of sites were subsequently excavated, mainly those located in the northern part of the area, as part of the salvage excavations program. Most of them, however, yielded evidence of the third millennium BC settlement only.

The data provided by these projects will be subsequently analyzed in regard to three features:

I. Settlement density and settlement pattern;

2. Changes in size and location of settled area within a site or site system;

3. Transfer of local centers within a regional network.

The first activity is a standard procedure in surveys. After plotting all the sites of the same period on the map, their relations are described by the number of settlements, their aggregate surface, a factor of changeability (ratio of settlements which continue to be occupied to the number of settlements which were abandoned and to the number of new settle-

2 I Tall Mefesh (BS-138), Tall Sahlan (BS-247), Tall Aswad (BS-245), Tall Jidle (BS-276) and Tall (Hammam) Ibn esh-Shehab (BS-275) by Mallowan (I946), Tall Hammam at-Turkman (BS-I75) by van Loon (I988), Tall Sabi Abyad (BS-I89) by Akkermans (I993; 2006; Akkermans et al. I993) and Khirbet esh-Shenef (BS-I70) by Bartl (I990).

22 Curvers I99I, 75-I73.

23 A similar approach was accepted in the later studies of this area (by Lyon and Wossink).

24 E.g. Kühne I978/79; Kühne - Röllig I980; I983.

25 Monchambert i984a; i984b.

26 Morandi Bonacossi I996; 2008; Kulemann-Ossen 2009. 
ments, located in places which were previously unoccupied). More elaborate methods include rank-size graphs and introducing Theissen Polygon boundaries. These two methods aim at reconstructing the structure of settlements and possible reflections of political or economical stratification within the settlement pattern. It is possible to apply all these methods to the results of a survey with full coverage of sites, which is moreover carried out within geo-political units. Only the Lower Khabur Survey and, to a lesser extent, The Balikh Drainage Survey meet these conditions (the Turkish border, which set a limit to the surveyed area from the North, excluded sites located within the territory of Turkey from consideration, even though they originally belonged to the same economical and political network as those to the south of the border).

The study of the second feature repeats, to some extent, one of the procedures described in the previous paragraph. It can be performed only in respect of the Upper Khabur Survey, because it was the only survey for which the distribution of material on each site/site system were published. Consequently, it is possible to record changes (or lack of changes) in the size and location of the settled area within the site or a cluster of sites.

The third factor aims at recording eventual transfer of regional centers within the existing settlement network. Such a transfer could have various causes, for instance, administrative, political, or economical; it could be related to changes in the road network or to an increase or decrease of population numbers, etc.

\section{Regional studies}

\subsection{Settlement density and patterns}

\subsubsection{The Upper Khabur Survey}

The methodology of this particular survey makes it difficult to evaluate the general features of settlement patterns at any period, and comparisons between periods are hardly possible. The observations presented below have thus a preliminary character and are based on the assumption that the surveyed sample of sites is representative of the whole region throughout its history.

Before I turn to the analysis, I would like to mention again that in this project sites were surveyed according to their topography (sherds of different sectors of the site were collected separately) and that period determinations were made in a way reflecting the density of sherds on the surface of sites (a four tier scale has been used). It should be noted that most of the sites discussed below also yielded some evidence of the Middle or Neo Assyrian periods as well as later occupations. On the one hand, this could influence the visibility of sherds belonging to earlier periods and, on the other, it may influence the identification of second millennium BC cultural periods (see above). 
While as many as 47 of $6_{3}$ surveyed sites represented second millennium settlements, the Middle Bronze period was represented on only 33 of them (Fig. I). ${ }^{27}$ Of this number, more than $50 \%$ (I7 sites) yielded low density of sherds, which was interpreted as evidence of a doubtful settlement or a settlement of limited intensity, while as much as seven were classified as very intensively settled. Of these seven sites only one (Tall Arbid) accounts for a larger settlement (site area of about $7 \mathrm{ha}$ ), one more is probably a large village (ca. 3.5 ha in area) while the others cover an area of less than I ha each.

This situation hardly reflects the actual settlement pattern of the period. As many as ig sites were identified in the Tall Brak Regional Survey; ${ }^{28}$ a number of them were very suggestive of real settlement density for the period. Moreover, the evidence of excavated sites demonstrates that a number of large and certainly more important settlements existed within the region (Tell Chagar Bazar), or were located on the border of the surveyed area (Tall Barri, Tall Brak, Tall Ailun or Tall Mozan). No doubt they constituted part of the Khabur Triangle area's settlement system. However, the fieldwork of Wilkinson ${ }^{29}$ and Ur ${ }^{30}$ in the area of Tall Beydar demonstrates that the southwestern part of the Khabur Triangle was very sparsely settled, confirming observations by Lyonnet, who found there exclusively minor or seasonal settlements.

For the Mittani period 40 sites are in evidence, ${ }^{3 \mathrm{I}}$ most of which were settled intensively or very intensively (24 and 6 sites respectively) (Fig. 2). Among these sites three groups of tells distinguished by size are clearly observable. The first group is composed of seven tells of approximately 7 to 5 hectares. The second, consisting of seven tells as well, extended over an area of 2-3 hectares. The remaining I 6 sites represent tells smaller than I hectare. Excavations at Tall Beydar have revealed that the site had an extensive lower city that was omitted by the survey, but it is difficult to determine its extent. As in the preceding period, there is some evidence for the existence of larger sites located on the border of the survey area. Besides the already mentioned settlements at Tall Brak, Tall Barri and Tall Mozan, some new, large sites appear, namely, Tall Fakhariya, Tall Hasake, Tall Hamidiya, and the still unexcavated Tall Beizari.

A comparison of the distribution of the MBA and the Mittanian sites shows a considerable degree of continuity. Of seven sites with very intensive MBA occupation, one is also very intensively settled during Mittani times, four are intensively occupied, and only two seem to be entirely abandoned after the end of the MBA. If we consider both very intensively occu-

27 Y. Nishiaki surveyed 44 sites located in the same area, of which I4 yielded MBA pottery and II Middle and Neo Assyrian pottery (Lyonnet 2000, 39, tab. 5). The Mittani period has not been distinguished in the summary of Nishiaki's survey, and no specific information on the sites was provided. For this reason they were excluded from further analysis.

28 Eidem - Warburton $1996,57$.

29 Wilkinson 2000 b, 15.35 .

30 Ur 2004, I78f., fig. 4.27.

3I Both the Tall Brak survey and the Tall Beydar survey summed up sites evidencing the Mittani and the Middle Assyrian pottery, and therefore they are not included in the present analysis. 


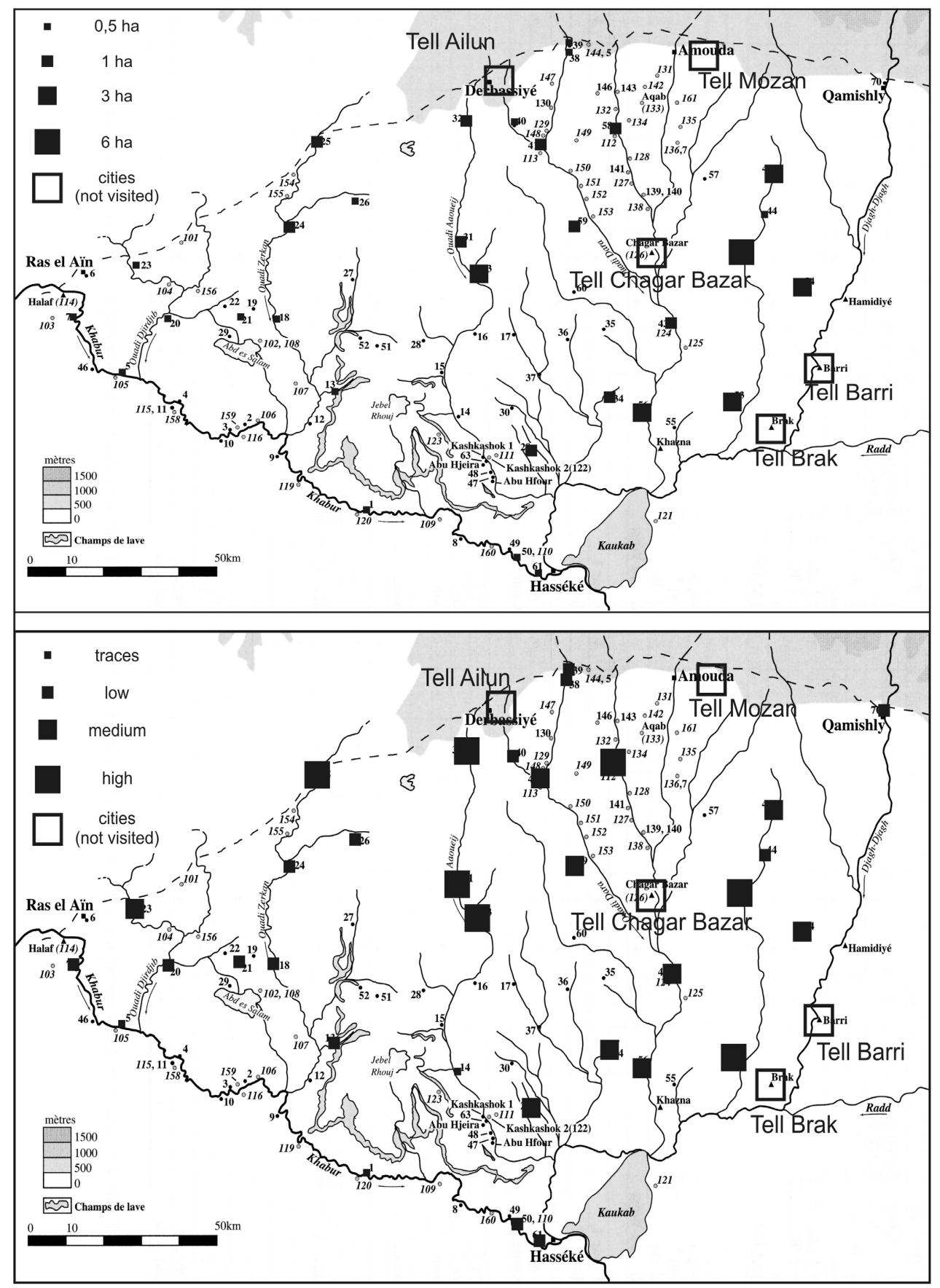

Fig. 1 Sites from the Middle Bronze Age identified in the Upper Khabur Survey. Top: according to area; Bottom: according to intensity of use. Drawing based on Lyonnet 2000, fig. I. 
pied and intensively occupied sites, the picture is similar: of I6 MBA sites, two were very intensively used during the Mittani times, Io were intensively used and only four were abandoned. Despite this high degree of settlement continuity it is very likely that changes occurred at the same time in the role and importance of most of the sites. Taking into account the fact that MBA settlements tend to be small, we have to assume that this reflects a development of these small sites (less than I ha in area) into larger villages or small townships. Four out of six sites, which were qualified as very intensively used during the Mittani period, were either not settled at all during the MBA period or show only traces of settlement. Consequently, they have to be considered as new locations of Mittani period settlement.

The results of the Khabur Survey, if they can be trusted, point to an increase in settlement density during the Mittani period. The overall number of sites increased by only $30 \%$ in comparison to the first half of the second millennium, but there is a very clear increase in the number of intensively or very intensively settled sites (it doubled during Mittani times), and there is also a very significant increase in the number of larger ("6-hectare" and "3-hectare”) sites: seven sites of each group existed during the Mittani period, in contrast to one site for each group during the Middle Bronze Age.

During the Middle Assyrian period, as far as it is reflected by the Khabur Survey, the situation changed again. The number of sites identified in the survey is higher than during the Mittani period. However, of the 48 sites, only one (Ain al-Qard, no. 38, an area of 2.3 ha) is listed as an intensively settled ${ }^{32}$. Three sites witnessed intensive occupation (Tell Ahmar, no. 45, an area of 4.9 ha; Tall Kdich, no. 32, an area of 0.8 ha; and Tall Hassek, no. 28, an area of I.5 ha), and nine sites showed traces of less intensive occupation (Fig. 3). The remaining sites (34 in number) were included in the list based on the presence of ten or fewer Middle Assyrian sherds. 33

The overall number of sites occupied during the Middle Assyrian Period is higher than during the preceding period, but on most sites only a few Middle Assyrian sherds were identified. There is considerable continuity - the six very intensively used Mittani sites are all occupied during the Middle Assyrian period as well: one very intensively, two intensively and the remaining three less intensively. Among the Middle Assyrian sites (leaving aside those with seasonal occupation) only two (sites no. 26 and 33) are new locations. Nonetheless, the number of intensively used Middle Assyrian sites is much lower than during the Mittani period (only four in comparison to 30 intensively or very intensively used Mittani sites) and the entire settlement pattern seems to be much more dispersed and less dense than before.

The distribution of the sites is similar to that of the MBA period: larger and more intensively used sites are located mainly in the northern part of the surveyed area. Small sites seem to be evenly distributed, though they are fewer in number in the eastern part of the area. This may also be the result of how the surveyed sites were selected in this area. 34

32 Anastasio 2007, I40, Abb. I36a.

33 Anastasio 2007, I40f.; Anhang B \& C.

34 Cf. Lyonnet 2000, fig. I. 


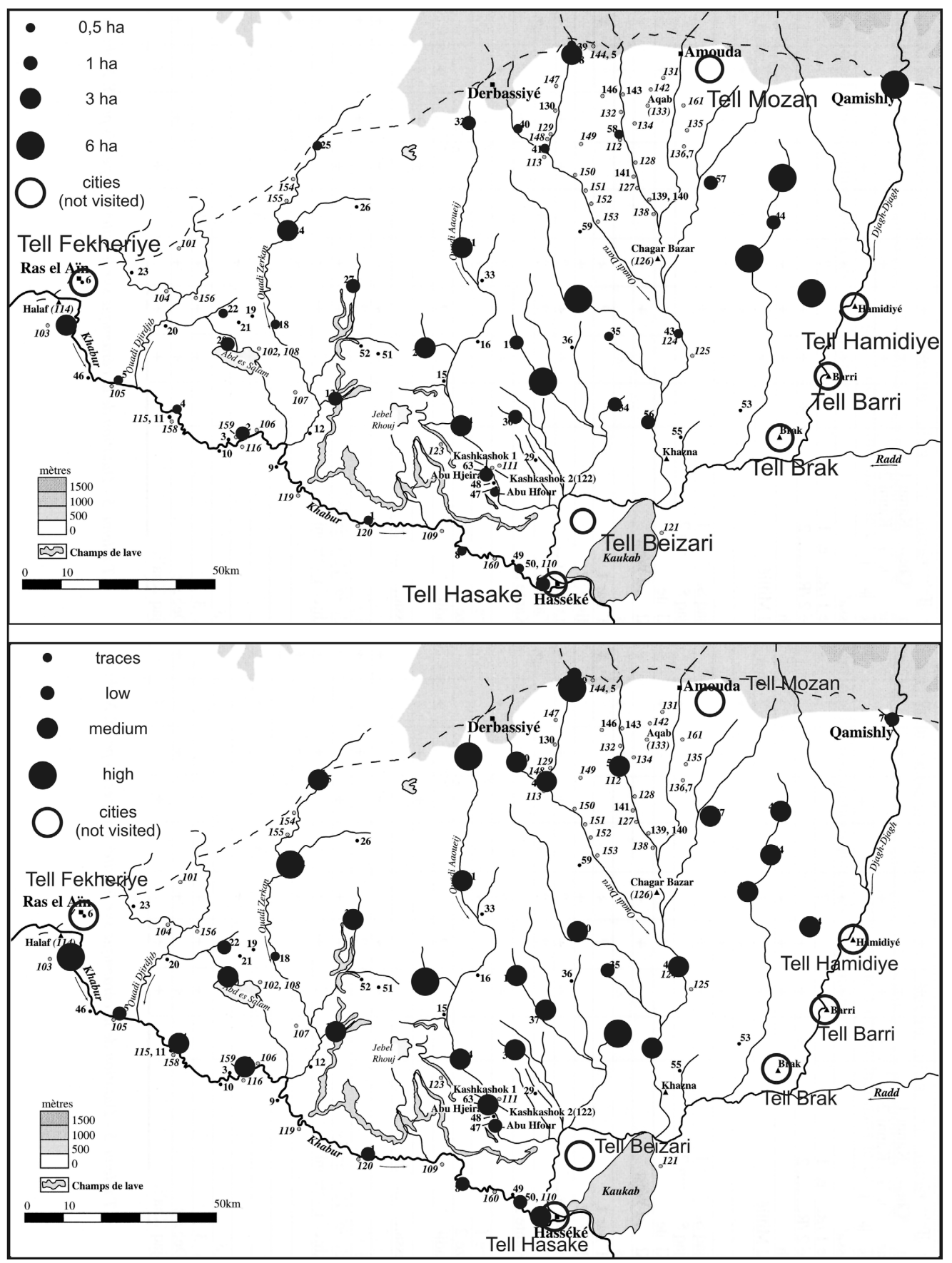

Fig. 2 | Sites from the Mittani period identified in the Upper Khabur Survey. Top: according to area; Bottom: according to intensity of use. Drawing based on Lyonnet 2000 , fig. I. 


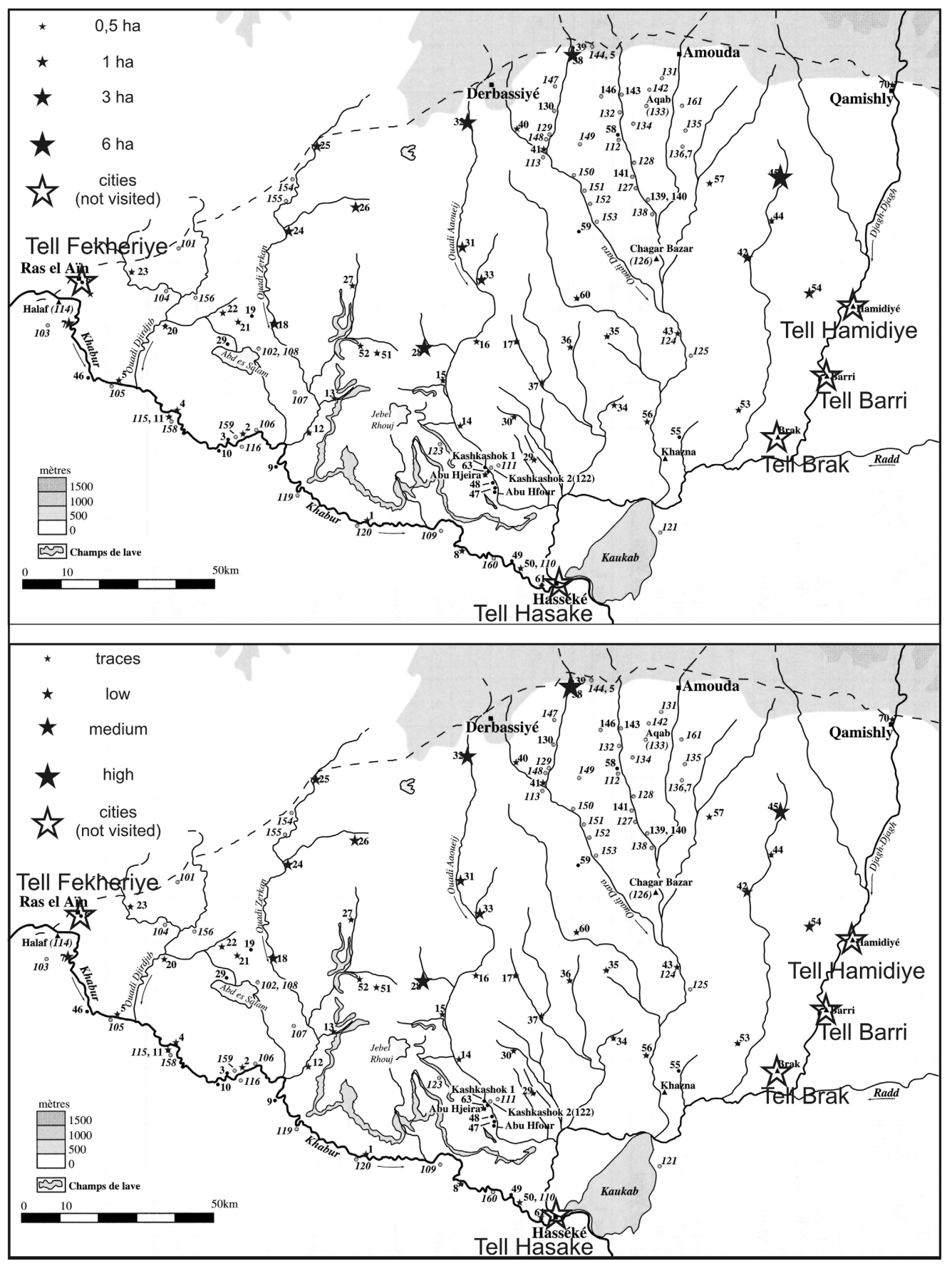

Fig. 3 Sites from the Middle Assyrian period identified in the Upper Khabur Survey. Top: according to area; Bottom: according to intensity of use. Drawing based on Lyonnet 2000, fig. I. 


\subsubsection{The Balikh Valley}

The first feature, which can be observed easily, is a clear-cut division of the surveyed area into a northern and a southern part. The southern part consists of the river valley itself. As it is located outside the rain-fed agriculture zone, settlements are located along the river, where agricultural land as a subsistence base for the villages is very limited. The northern part is located within the $250 \mathrm{~mm}$ isohyet and includes not only the river valley but the valleys of some seasonal streams as well (of which Wadi Qaramokh and Wadi Humar were not surveyed by Curvers). ${ }^{35}$ Agricultural land is much more readily available there, and the core of this area is constituted by the Hammam at-Turkman plain; thus, it could be expected that the northern part of Balikh drainage would be much more intensively occupied, as was confirmed by the survey.

As the fieldwork carried out by Akkermans and Curvers ${ }^{36}$ and that of Lyon 37 differ considerably in their conclusions, they will be presented separately here, and only at the end of this section will an attempt be made to integrate them.

According to Curvers, ${ }^{38}$ the MBA settlement in the southern part of the valley comprises 26 sites (Fig. 4a). It mainly consists of small settlements (eight sites of an area of about I hectare and 16 sites of an area around 0.5 hectare or less). Only two larger settlements (each approx. Io ha in area) were identified in this section of the valley, forming a cluster of sites located close to each other on the opposite banks of the Balikh: Tall Seman (BS-83) on the western bank and BS-84 on the eastern one. A widening of the river valley provided a larger area suitable for agriculture and was a major reason for the development of both sites. The southernmost $\mathrm{I}_{5} \mathrm{~km}$ of the valley have no settlements. This feature may be explained by the narrowness of the valley, the presence of soils with high gypsum content (i.e. of low fertility), and the proximity of a large site, Tall Bi'a (Tuttul), near the BalikhEuphrates confluence.

In the northern part of the drainage 45 sites were identified (Fig. $4 \mathrm{~b}$ ). Similarly to the south, this area is dominated by very small sites (27 sites of an area of 0.5 ha or less) but larger sites ( 2 ha or more) are much more abundant (Io sites). Three urban centers were identified, all with an area of about 6 hectares: Tall Hammam at-Turkman (BS-I75) located on the confluence of the Balikh and Wadi Sluk, Tall Sahlan (BS-247), located ca. Io km upstream the Balikh, near to its confluence with Wadi Jellab, and Tall Abyad (BS 280) located opposite Tall Sahlan. The average site area both in the south and in the north is similar: around I.5 ha.

35 Some sites located in the Balikh Valley and in Wadi Qaramokh were surveyed by a Spanish team and published in an interim report, which does not give the dimensions of sites (Córdoba I988). The Wadi Hamar area was partly covered by a survey conducted by Alexander Pruss, which focused on an area with a radius of Io km centered on the site of Kharab Seyyar (Pruss I990).

36 Curvers I991.

37 Lyon 2000.

38 Curvers I99I, 20I-207. 


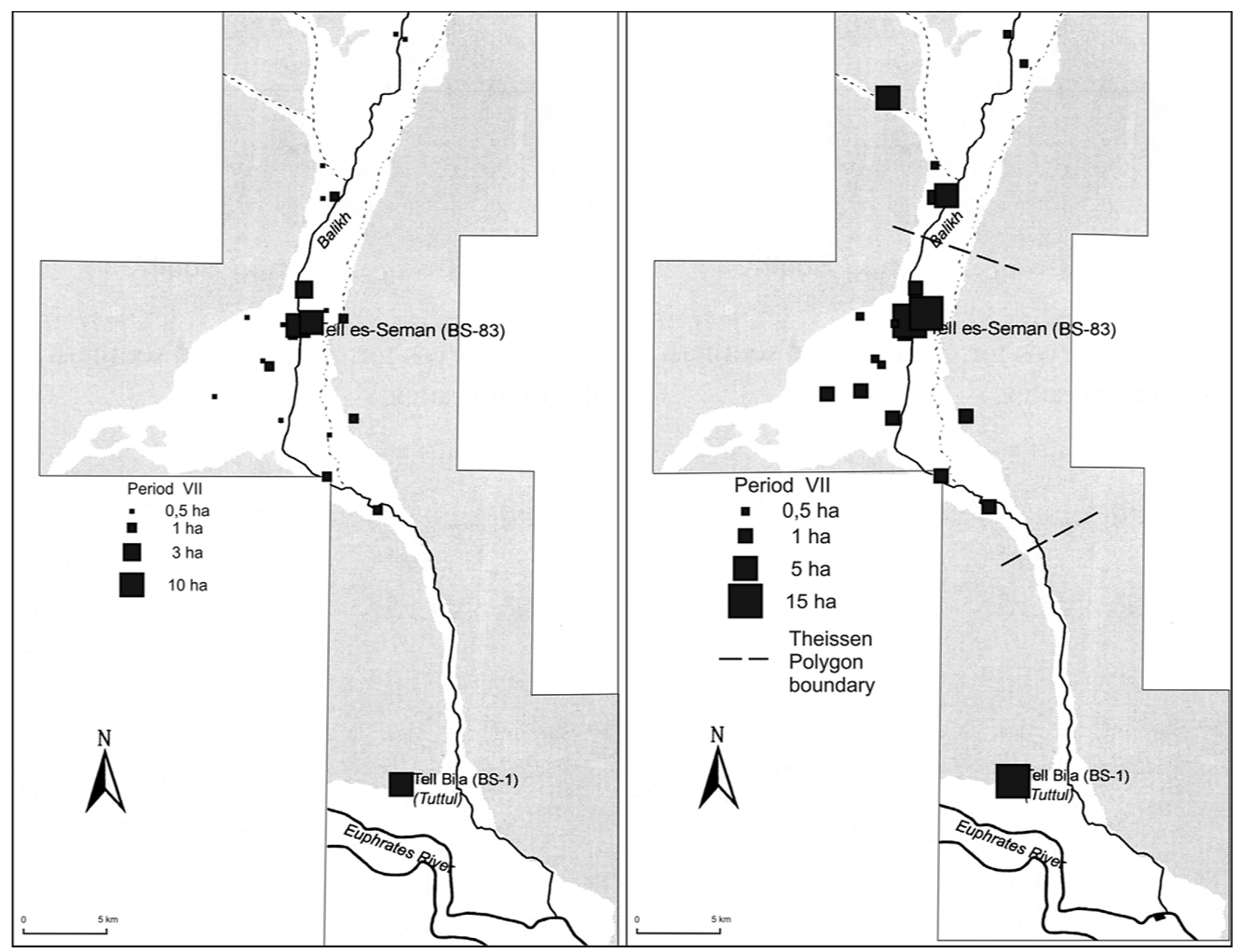

Fig. 4a | Sites from the Middle Bronze Age (Hammam at-Turkman period VII) in the Southern part of the Balikh Valley. Left: according to Curvers; right: according to Lyon. Drawing based on Lyon 2000, fig. 2.

According to Curvers, the settlement dynamics point to the intensification of land use during the Hammam et-Turkam VIIB period. He assigns most of the identified sites to this period $(63$ sites registered, 24 of which are located in the southern and 39 in the northern part of the area). Period VIIA featured only about half of the number of sites (34 sites registered, $\mathrm{I} 3$ in the south and 2I in the north) but the sites are generally of larger dimensions (average area close to $2 \mathrm{ha}$ ). During the VIIC period the number of sites decreases in comparison to period VIIB (46 sites registered, I7 in the south, 29 in the north). In the south a trend towards reduction of the site area is observable (average of ca. I ha), which, in my opinion, stems from the fact that period identifications are often based on the retrieval of a single characteristic sherd.

It has to be noted that there is a significant inconsistency between the already quoted data, and those published by Lyon. ${ }^{39}$ In his study Lyon lists only 50 sites ${ }^{40}$ with occupation

39 Lyon 2000, 97f., tab. 2. 


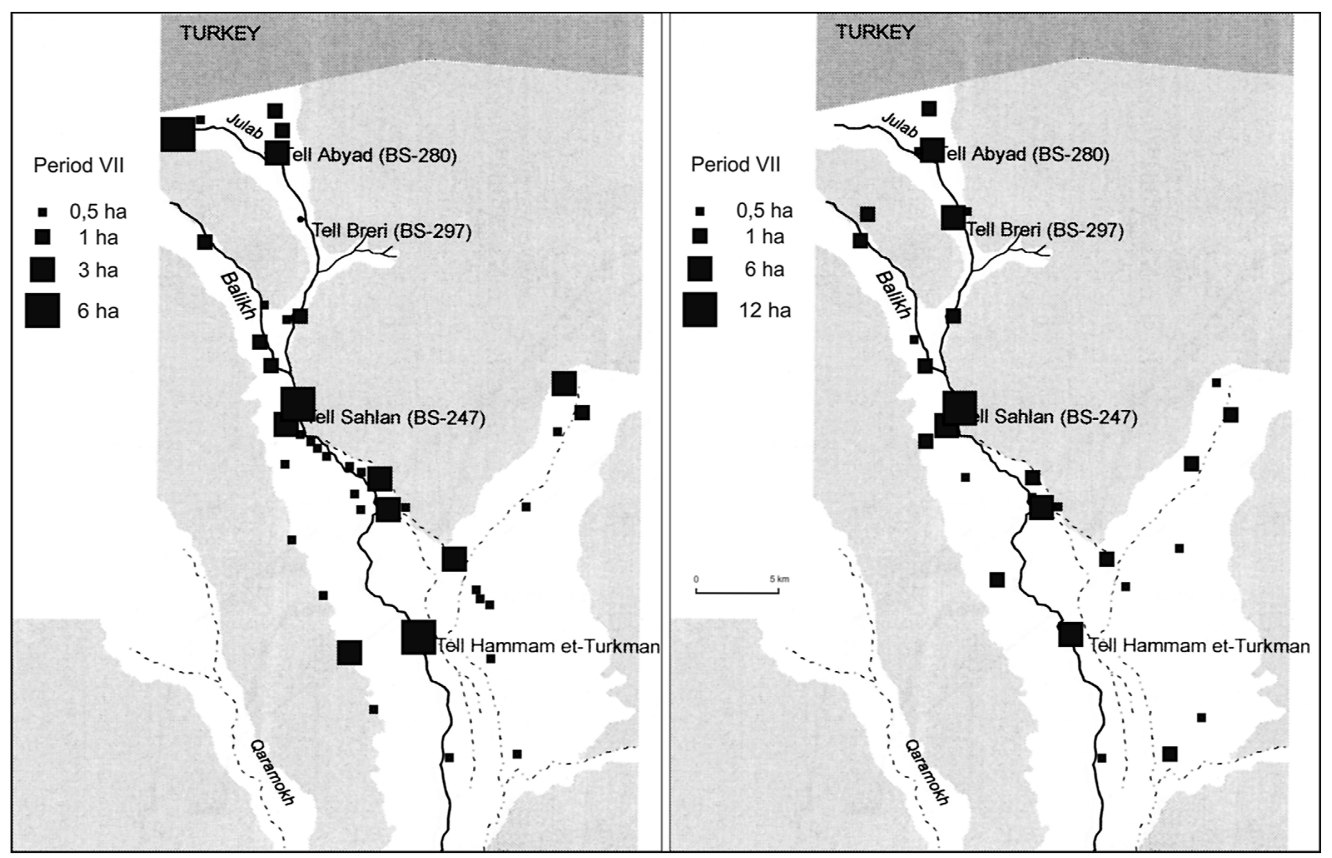

Fig. 4b | Sites from the Middle Bronze Age (Hammam at-Turkman period VII) in the Northern part of the Balikh Valley. Left: according to Curvers; right: according to Lyon. Drawing based on Lyon 2000, fig. 2.

during the MBA period, but as the focus of his study was on the latter part of the second millennium BC he neither attempted a more thorough analysis of the settlement patterns of the MBA period, nor observed the division of the MBA into three periods. Another significant difference between Lyon's study and that of Curvers is that the first gives much higher figures of the estimated site area than the second. Consequently, Lyon's average site area is nearly twice as large as Curvers' (2.78 ha against I.5). Apart from Tall Bi‘a (BS-I, 25 ha), he identifies one large site in each part of the Balikh Valley: Tall Sahlan (BS-247, I6 ha) in the North, and Tall Saman (BS-83, I7 ha) in the south. Sites of medium area (6-4 ha) are not evenly distributed: there are four of them in the north (Tall Abyad, Tall Breri, Tall Jittal, Tall Hammam at-Turkman) but only two in the south (Tall Khadriya and Tall Sabaniyeh; the latter was not identified by Curvers at all). These last two sites are located on the Wadi Isa, in a zone on the border between the northern and the southern part of the Balikh Valley. The six medium sized and two larger sized sites account for eight territorial/administrative

40 Wossink convincingly demonstrated that at least five sites need to be removed from the original list of Curvers: BS-22I and BS-243 were mistakenly interpreted as sites (they were not listed by Lyon), and BS-I70, I89 and I9I which did not yield MBA pottery during excavations (Wossink 2009, 8I). 


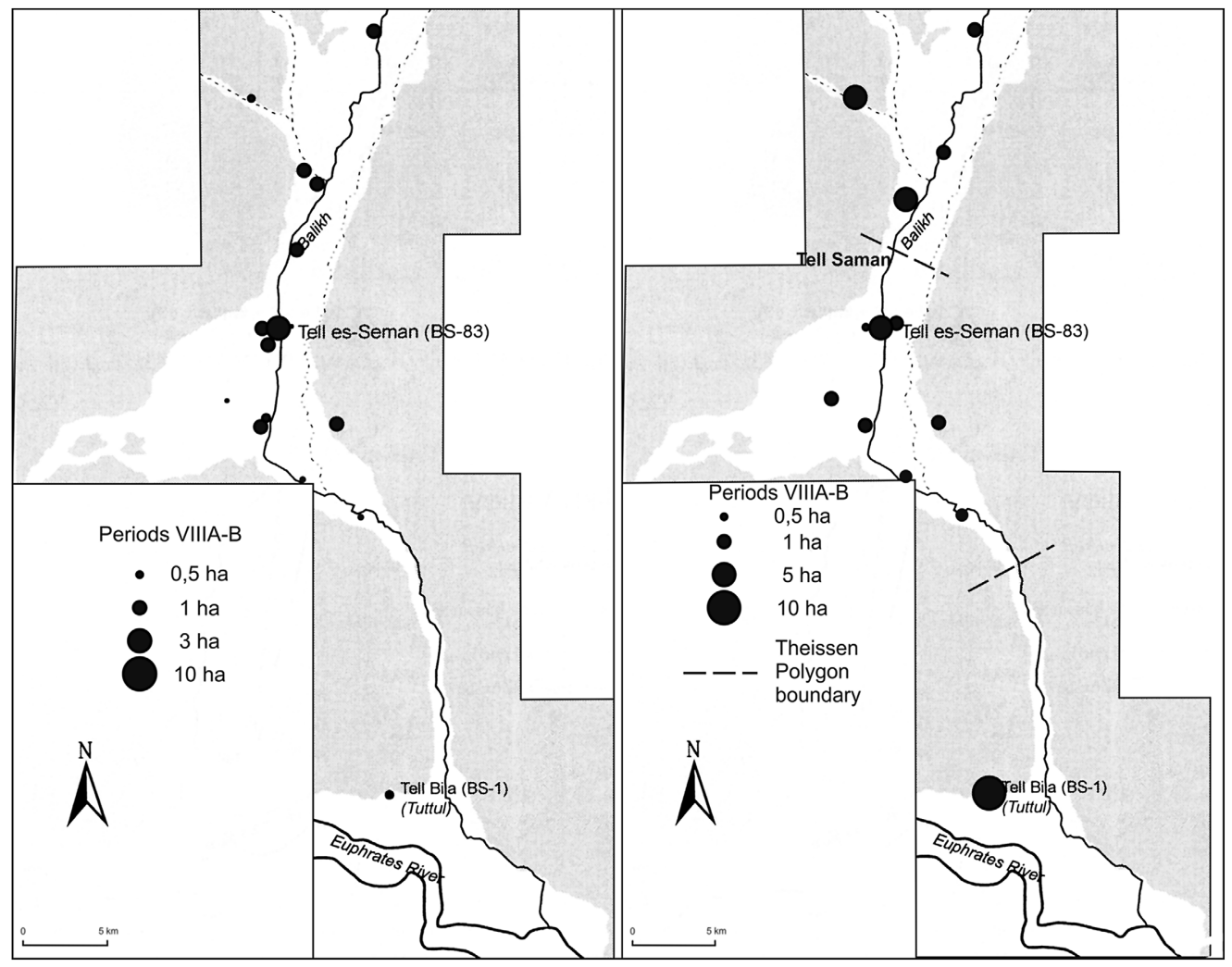

Fig. 5a | Sites from the Mittani period (Hammam at-Turkman period VIIIA-B) in the southern part of the Balikh Valley. Left: according to Curvers; right: according to Lyon. Drawing based on Lyon 2000, fig. 4.

units in a reconstruction based on application of the Thiessen polygon method:4 ${ }^{\mathrm{I}}$ two in the south and the remaining six in the north. Each of these units "controlled" a zone in which four to ten small settlements were located. According to the rank-size evaluation, the entire area of the Balikh Valley shows a high degree of integration, but when split into two sections, this picture changes. Two centers located in the southern part of the valley (plus Tall Bi'a) seem to form relatively independent sub-systems, with Tall Bi'a controlling mainly the Euphrates valley area. ${ }^{42}$ Six units present in the north probably belong to two larger entities, whose centers were most likely located more to the north, beyond the Turkish border (likely candidates are Harran and Sultantepe). 43

4I Lyon 2000, fig. I5.

42 Some texts, mainly from Mari, demonstrate however, that its control over the southern part of the Balikh Valley was considerable (Krebernik 200I, I2).

43 Lyon $2000,97 f$. 


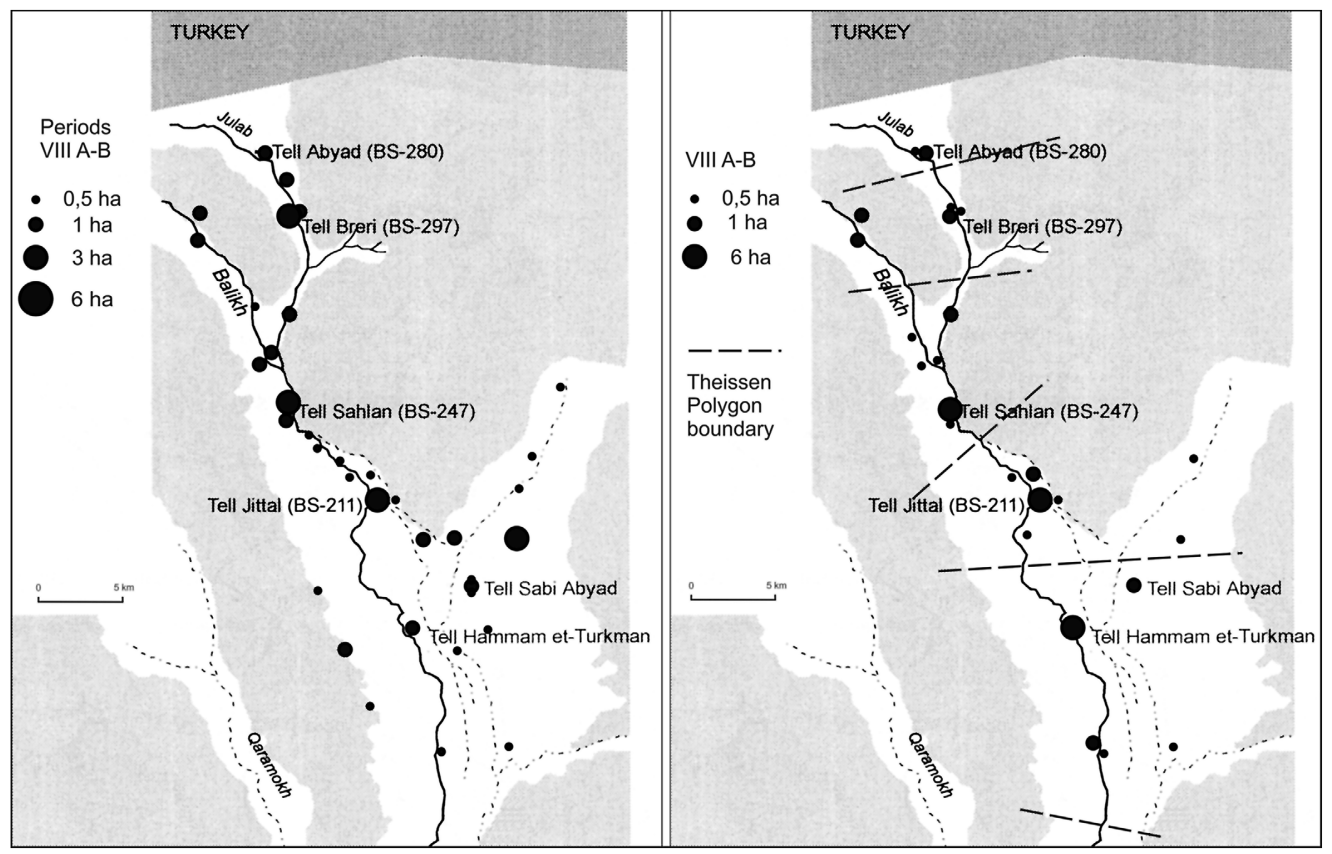

Fig. 5b | Sites from the Mittani period (Hammam at-Turkman period VIIIA-B) in the Northern part of the Balikh Valley. Left: according to Curvers; right: according to Lyon. Drawing based on Lyon 2000, fig. 4.

The Mittani period is less well represented in the area of the Balikh Survey than the preceding period.

According to Curvers, 44 only I7 sites from this period are present in the southern part of the valley, most of which fall into the category of very small sites (0.5 ha or less) (Fig. 5a). Only one site is of moderate size - Tall Seman (BS-83). Its estimated surface area was 3 ha and despite a reduction in size it clearly continues to serve as a local center. Its "twin site", BS-84, shows traces of occupation during the VIIIA period but was probably abandoned later. Sites tend to be much smaller than in the preceding period; on average they are less than I ha and decrease in size during the VIIIB period.

Mittani period sites are much more abundant in the northern part of the area (Fig. $5 \mathrm{~b}$ ). Among 36 identified sites $50 \%$ are very small, but sites of an area of ca. I ha are nearly equally numerous (I5 such sites were identified). Only three local centers can be identified, but they are considerably smaller than the MBA centers of the area, covering an area of 3-4 hectares each. It should be noted that the settled area on several high mounds was calculated in a very particular way, reflecting the situation encountered at Tall Hammam at-Turkman, where only one large mansion seems to exist on the top of the tell. For instance, on 
Tall Sahlan, where period VIIB and period VIII pottery was collected in the same areas (on the top and all the slopes of the tell), the area calculated for period VII is 7.5 ha, and for period VIII it is estimated at only 3 hectares. A similar situation is encountered at Tall Abyad, where period VII occupation covered 4.8 ha and, despite the fact that period VIII sherds are encountered on all the slopes, the area of settlement is estimated at only I. 5 ha. 45 Tall Sahlan (BS 247) and Tall Jittal (BS-2II) are located on the eastern bank of the Balikh; this second site probably took over the role of a local center from Hammam at-Turkman. A third local center, Tall Breri (BS-297), is located on the western bank of Wadi Jellab, nearby Tall Abyad, another likely candidate for such a role. It seems that the major center of the area was located outside of the surveyed section of the valley; a likely candidate is Harran, which, according to cuneiform texts, was referred to as a halsu, or "district", indicating it was an administrative center. ${ }^{6}$ Sites located in the northern part of the valley are on average bigger than those in the south (the mean value of site area is slightly above I hectare).

An important feature observed by Curvers is a significant decrease in the settlement density during the VIIIB period, visible mainly in the northern part of the surveyed area. The number of sites drops from 36 to 22 and their aggregate area from 36 to 27 hectares. But again, this conclusion may be biased by a limited ability to recognize sherds typical of sub-periods of Mittanian occupation at Tall Hammam at-Turkman.

Just like in the previously discussed MBA period, Lyon's site area estimates are considerably higher than those of Curvers. The aggregate area of settlements represented by $4 \mathrm{I}$ sites is 94.4 ha, i.e. three times as much as in the previously discussed analysis. According to Lyon47, despite a slight decrease in the number of sites and in the aggregate sites area, the settlement pattern of the Mittani period follows that of the MBA. The largest site is still Tall Bi'a, located in the Euphrates valley, while seven smaller sites (of an area from 8 to 4 hectares) that serve as local centers, are dispersed predominantly in the northern part of the valley, exactly on the same sites as in the previous period. Harran, located to the north, behind the present-day border with Turkey, served as another higher-ranking center for the northern part of the valley. As in the preceding period, two clusters of sites are found in the south (one centered on Tall es-Seman, the other on a pair of sites, BS-II7 and BS-I39). The most extensive of the three northern clusters is Tall Hammam at-Turkman, which included Tall Jittal as well. The second cluster is centered at Tall Sahlan, while the third included two sites of similar area: Tall Breri and Tall Abyad.

The Middle Assyrian period (Hammam at-Turkman period VIIIC) is represented by an even smaller number of sites. The thesis by Curvers lists only eight tells from this period present in the southern part of the valley and as many as 20 in its northern section (Figs.

45 Estimates of Lyon are as follows: Tall Hammam at-Turkman - 3,9 ha, Tall Sahlan - 8,3 ha, Tall Abyad - 4,9 ha (Lyon 2000, Tab. 2).

46 Postgate I973.

47 Lyon 2002, 99-100 


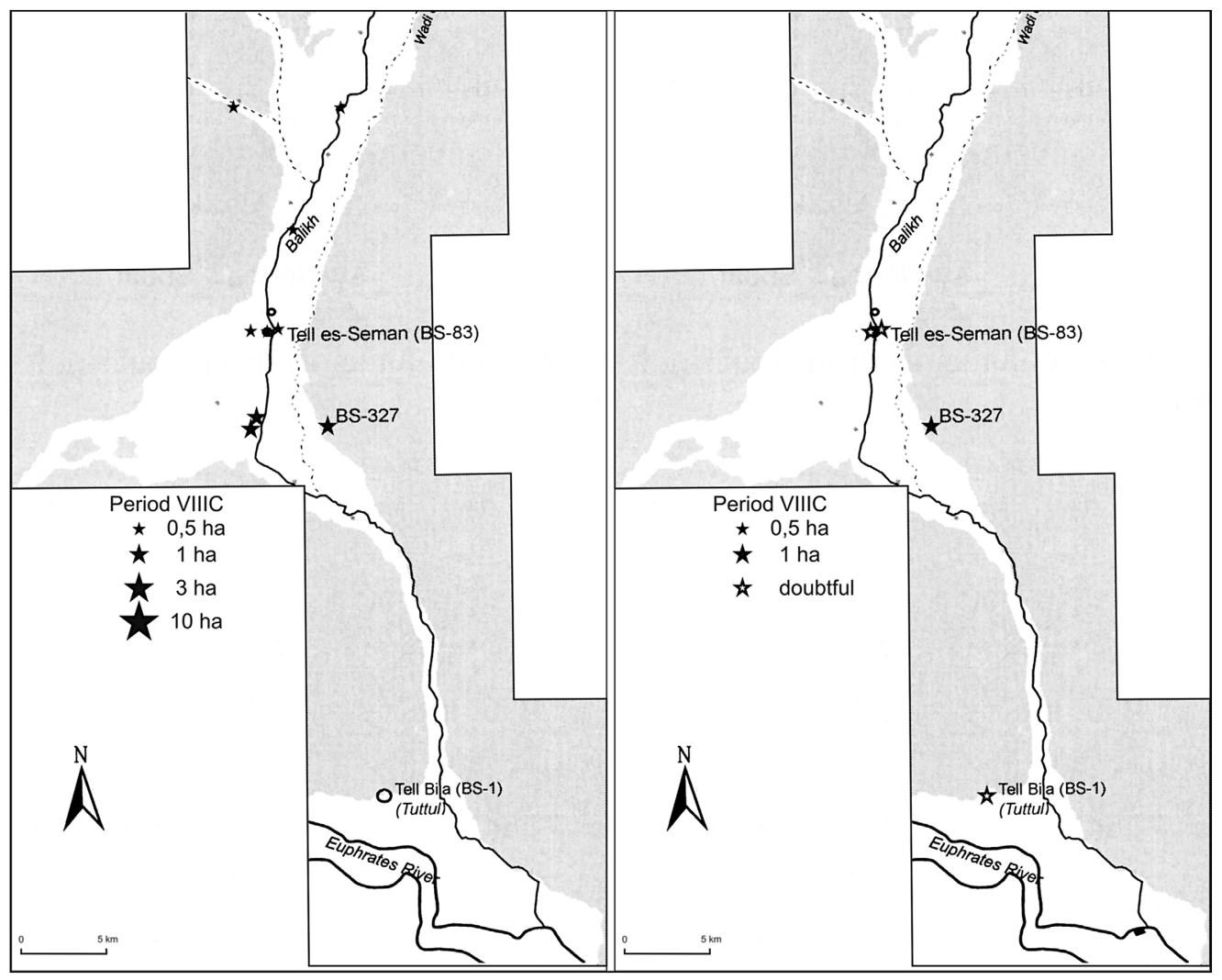

Fig. 6a | Sites from the Middle Assyrian Period (Hammam at-Turkman period VIIIC) in the southern part of the Balikh Valley. Left: according to Curvers, right: according to Lyon. Drawing based on Lyon 2000, fig. 7.

6a-b). These numbers differ only slightly from the number of sites from which period VIIIB pottery has been identified (II and 22 sites, respectively).

In the southern part of the Balikh drainage, only small sites were identified (three of them have an area of about I ha, others are 0.5 hectare or smaller), located on both sides of the river. BS-327, belonging to a group of sites of I ha in area, has a somewhat special position: it is located on the edge of a high river terrace, in a position providing a good view of the entire section of the river valley. Curvers assumed that a Middle Assyrian military post was located there.

In the northern part of the area the Middle Assyrian evidence is similar to that of the Mittani period. All three local centers (Tell Sahlan, Tall Breri and Tall Jittal) continue to exist with no change in respect to their settled area. The number of very small sites is the highest (II), but sites of an area of around I hectare are relatively numerous (six sites, all occupied during the previous period). Generally speaking, the Middle Assyrian period shows a con- 


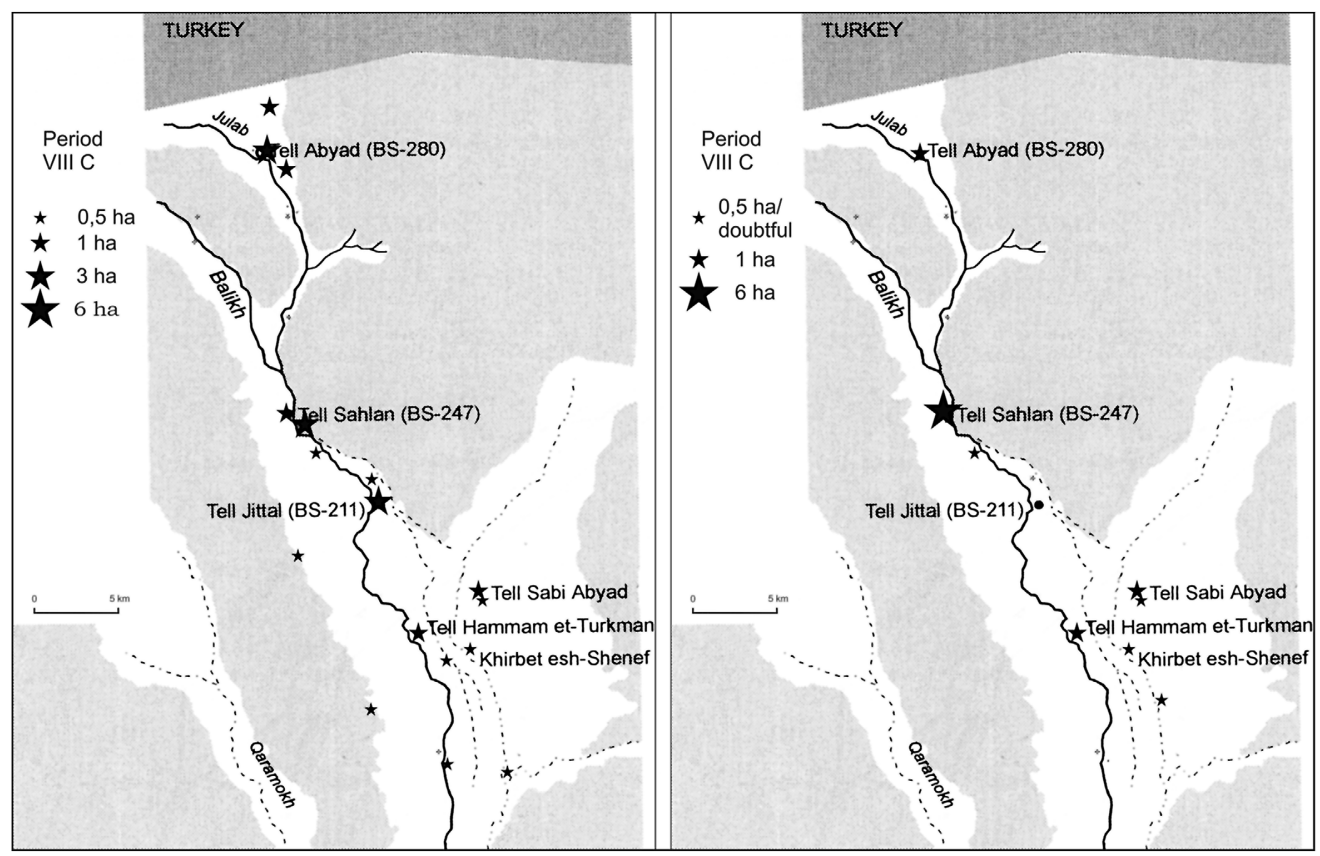

Fig. 6b | Sites from the Middle Assyrian Period (Hammam at-Turkman period VIIIC) in the northern part of the Balikh Valley. Left: according to Curvers, right: according to Lyon. Drawing based on Lyon 2000, fig. 7.

tinuation of the earlier settlement pattern; however, a decline in settlement is evidenced in the southern part of the Balikh Valley.

Again, Lyon's evaluation of the situation differs considerably from that of Curvers. A misunderstanding may initially have been caused by Curvers's identification of the Middle Assyrian period as VIIIC, in contrast to Lyon's identification of the same period as VIIIB. The number of sites listed by Lyon is remarkably low: he lists only six sites with confirmed occupation for this period for the whole survey area (Tall Sahlan, Tall Jittal, Tall Sabi Abyad I, Tall Hammam at-Turkman, Khirbet esh-Shenef in the north and Tall Abbara (BS-327) in the south). Six more sites yielded limited evidence (one or two Middle Assyrian sherds) and three more (including Tall Abyad and Tall Bi'a) are marked by question marks only. The biggest site, Tall Sahlan, has over 8 ha of area covered with occupation, three sites (including Tall Sabi Abyad I) are about 2 ha and others are smaller still. Nearly all the sites are located north of Tall Hammam at-Turkman and, according to Lyon, reflect an attempt to intensify agricultural exploitation of the rain-fed part of the Balikh valley. He interprets site BS-327 not as a sentry post (as Curvers did) but rather as a station on a road leading down the Balikh to the Euphrates Valley.

The reconstruction of settlement pattern trends in the Balikh Valley presented by Curvers needs to be modified significantly in light of Lyon's work. Curvers claimed to see a 
trend toward a decrease in the number and size of settlements throughout the second millennium BC. Yet he observed a high degree of continuity, at least between the Middle Bronze Age settlement pattern and that of the Mittani period (well articulated when sites featuring period VIIB-C and VIIIA occupations are compared). All Mittani settlements identified in the southern part of the Balikh drainage were already occupied in the preceding period, and in the north only two sites, BS-I99 and BS-296, are new settlements. Abandonment of earlier sites can be observed mainly in the south, where II of 25 MBA sites are abandoned, while in the north only six out of 39 sites show a break in occupation. This tendency continues during the Middle Assyrian period. Again, the southern part of the area demonstrates a high abandonment factor: of I6 Mittani sites only seven have Middle Assyrian occupation, and one site (BS-I23) was newly founded. In the north the situation is slightly different. While $35 \%$ of sites were abandoned (I4 out of 36 ) there are no newly founded sites. These changes, together with the decrease in the settled area, point towards a settlement crisis affecting the Balikh area towards the end of the Late Bronze Age, a crisis which affected mainly the southern part of the area.

According to Lyon, the Mittani period exhibits a significant degree of continuity in the settlement pattern. A decrease in the number and the area of sites does not seem to affect the settlement pattern in the valley; eight clusters of sites from the Middle Bronze Age continue to exist and are centered around exactly the same larger sites. The continuity factor is about $70 \%$, while only very few sites are newly founded settlements. A drastic change in the settlement pattern appears at the beginning of the Middle Assyrian period. Around $80 \%$ of earlier sites were abandoned, and new locations are even less numerous than before. ${ }^{4}$ Almost all the larger sites continued into the Middle Assyrian period, as if the Assyrians were taking over local centers in order to control the country. Yet, a systematic surface collection at Tall Jittal (BS-2II)49 allowed Lyon to observe that the Middle Assyrian occupation was of limited extent and was located only in the highest part of the site. A similar location was chosen for the Middle Assyrian settlement at Tall Sabi Abyad and Tall Chuera. According to Lyon this suggests that Assyrians constructed new, smaller, and probably protected settlements on most of the older sites, forming a close cluster of such sites; in the case of the Tall Sabi Abyad area, the sites are less than $4 \mathrm{~km}$ apart. Moreover, some excavated sites (Tall Sabi Abyad, Tall Jidle, Tall (Hammam) Ibn esh-Shehab, and Tall Hammam at-Turkman) exhibited conflagration and abandonment levels preceding the establishment of the Middle Assyrian settlements, suggesting that there was no direct continuity between the settlements of these periods.

Another tendency that can be observed during the whole latter part of the second millennium in the southern part of the Balikh drainage is the progressive abandonment ${ }^{\circ}$ or

48 Lyon 2000, I02 f., figs. 9-II.

49 Lyon 2000 , I03, fig. I6.

50 It has to be noted, that the population of the Balikh Valley reached its maximum, estimated at $14000-24000$ persons, during the VIIB (mid-MBA) period (Wossink 2009, 87 f.). 
shrinkage of sites. During the Middle Assyrian period there were only one confirmed and two doubtful settlements. This trend is generally interpreted as a reflection of environmental change that created more arid conditions.

\subsubsection{The Lower Khabur Valley}

The settlement pattern in the Lower Khabur Valley is clearly influenced by environmental factors. In the southern part of the valley, archaeological sites are much more widely dispersed. For instance, the mean density of sites for the Neo Assyrian period is 0.098 of site per square kilometer in the area located south of the contemporary city of Saba'a wa-Arbain. By contrast, the settlement density in the north is $0.5^{\mathrm{I}}$ of site per square $\mathrm{km} . \mathrm{.}^{\mathrm{I}}$ Consequently, the distance between cities in the northern part of the valley (for the Middle Assyrian period) averages I3.6 km (in a range from II.5 to I6 km), while south of Tall Agaga it increases to $32.5 \mathrm{~km}$ on average (in a range 29.5 to $35.5 \mathrm{~km}$ ). The same observation is valid for other periods, for instance the Early Bronze Age. ${ }^{2}$ It is also noticeable that there are segments of the valley where no settlements are attested - they correspond to the parts where the river valley is very narrow and where as a result there was very little or no flood plain (land suitable for agriculture). 53

The second millennium settlements are located mainly on the flood plain of the river ( $82 \%$ and $78 \%$ of settlements, respectively, for the earlier and the latter part of the millennium). Later, in the Neo Assyrian period, this proportion drops to $54 \%$; this is probably a result of the construction of irrigation canals during the early first millennium. 54

While the Middle Bronze period settlements in the Khabur Valley are relatively numerous (I8 sites out of 33 sites settled during the second millennium), five of these sites yielded a very limited number of identifiable sherds, pointing to an incidental settlement (Fig. 7). A significant feature is that the presence of the MBA period is confirmed on all large sites, and on four of them (Tall Šeh Hamad, Tall Ašamsani, Tall Fadgami and Tall Taban) the settlement continues throughout the second millennium BC. The number of sites located on the western bank of the river is only slightly lower than on the eastern bank.

During the Mittani period a considerable difference in the ratio of towns to villages can be observed: 24 settlements from the Mittani period, ca. $75 \%$ of the total settlement number, are small, countryside settlements. But it is the Middle Assyrian period which brings a significant change in the settlement pattern (Fig. 8). Out of the nine Middle Assy-

5I Morandi Bonacossi 2008, I89.

52 Ergenzinger - Kühne I99I, I82, fig. I39.

53 Morandi Bonacossi 2008 , I90.

54 Morandi Bonacossi 2008, I90. This change is observable mainly in the southern part of the valley, where most of the settlements are located on the terrace above the valley - which was impossible during the earlier period. By comparison, in the north there are only three settlements from this period located on the terrace. 


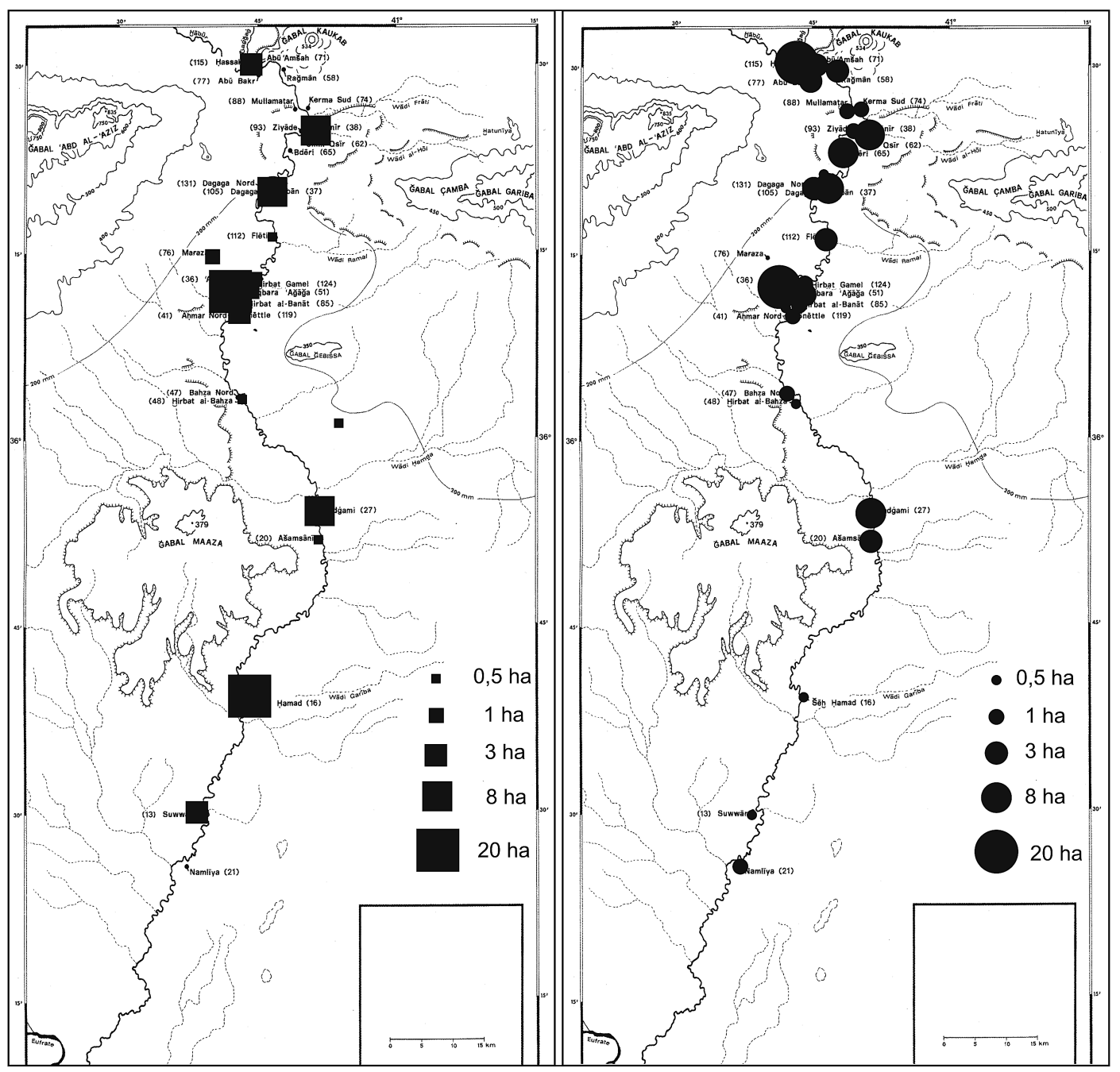

Fig. 7 | Sites identified in the Khabur Valley according to the results of the TAVO survey.

Left: Middle Bronze period; right: Mittani period. Drawing based on Morandi Bonaccosi 2008, fig. 9.I.

rian settlements, six are cities, and only three are villages. Consequently, a smaller number of sites accounts for the same settled area within settlements (72 to 74 hectares of settled area) and thus the ratio of village to town populations is I : 9 . By comparison, in the Neo Assyrian period the ratio is I2 : I. Nearly the entire Middle Assyrian population in the Khabur Valley lived in towns, which were probably walled for protection.

Settlements in the steppe appear in the EBA and then resurface in the Neo Assyrian period. During the second millennium they are the exception rather than the rule. Two Middle Bronze sites located away from the river were discovered: Tall Gayyir, located $30 \mathrm{~km}$ 


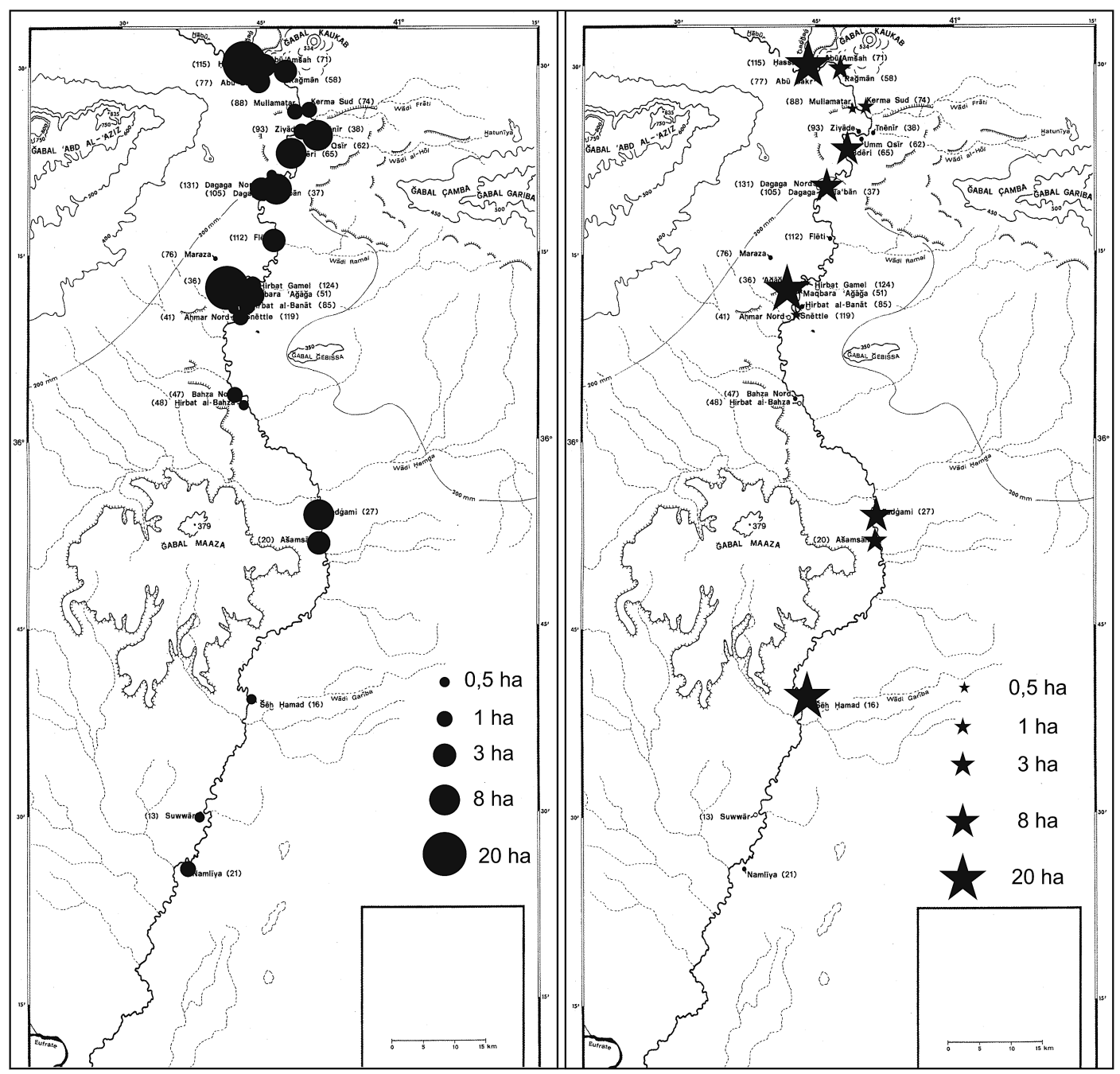

Fig. 8 | Sites identified in the Khabur Valley according to the results of the TAVO survey.

Left: Mittani period; right: Middle Assyrian period. Drawing based on Morandi Bonaccosi 2008, fig. 9.I.

to the east, and Tall Manah, with traces of occupation only, about $20 \mathrm{~km}$ to the east. It is also necessary to mention a Middle Assyrian attempt to use the Wadi Agig area for what seems to have been a temporary settlement. 55

The Lower Khabur Valley shows two significant changes in the settlement pattern. The first is a remarkable increase in the number of small settlements. This is clearly an attempt to maximize agricultural production in the area by gaining better control of the agricultural 
land during the Mittani period. The second change appears at the beginning of the Middle Assyrian period, when nearly all small sites were abandoned and most of population of the area inhabited cities and towns, almost all of which were located on the eastern, "Assyrian" bank of the river. This change may be explained as an attempt to increase control over the population in the area and, in addition, to make it less vulnerable to enemy raids.

\subsection{Changes in the size and location of settlements within a site or site system}

Excavations confirm that during the latter part of the second millennium BC several high tells in the Khabur Triangle (see below), which were built on third millennium deposits, were abandoned. Instead, new villages or farms were built in flat areas that were often located in the neighborhood of these tells. This tendency has rarely been remarked upon. Thus, it will be of interest here to check how typical this feature is of the Khabur Triangle area and if it is observable in other areas as well.

\subsubsection{The Upper Khabur}

The excavations at Tall Abu Hafur - the Tall Abu Hafur East cluster of sites, Tall Arbid, Tall Beydar and, to some extent, Tall Brak - yielded evidence of the abandonment of high mound and the establishment of a new settlement in a new place, usually at the base of a high tell.

Tall Abu Hafur is a small site located in the lower valley of Wadi Awij, on the right bank of an unnamed tributary of this seasonal stream. It was excavated by a Polish mission as part of the North Hasake Salvage Project between I988 and I990. The site yielded materials dating to the Ubaid, Uruk, and EJ III-IV periods. Another, later site was identified by the Polish mission on the opposite bank of the wadi and named Tall Abu Hafur East. It was excavated for one season in 1990 and yielded strata beginning with the Mittani period and continuing into the first millennium BC.

A similar situation can be found at Tall Beydar, the well known third millennium site. Tall Beydar had been abandoned towards the end of the Akkadian period and was resettled for a short period during Seleucid times. However, a substantial lower city located to the west of the village of Tall Beydar (and of the tell itself) was identified by a survey and excavated by soundings..$^{6}$ They revealed the presence of Mittani and Neo-Assyrian period occupation. This flat site, called Tall Beydar II, reached about too ha in area during Neo Assyrian times. Bertille Lyonnet ${ }^{57}$ did not identify this tell in her survey, although she noted the

56 Brettschneider 1997 .

57 Lyonnet 2000, 22.34, fig. 9 . 
presence of a minor occupation of these two periods on the main tell. Extensive excavations carried out there since 1987 have since disproven this observation.

The situation at Tall Arbid is a little more complicated, because the remains of Mittani settlement activity have been identified on two separate spots some 250 meters apart. Excavations on the highest part of the mound showed remains of a craft activity area and two Mittani graves.$^{8}$ A proper settlement was discovered on a secondary, much lower tell located to the west and designated as Sector A. This small tell was reoccupied during PostAssyrian and Hellenistic times, while on the main tell no settlement later than the Mittani period has been found. Like Tall Beydar, the Arbid site was surveyed by Bertille Lyonnet, who indicated the presence of occupation dating to the Mittani period on the entire main tell and observed traces of minor occupation of Middle, Neo and Post Assyrian periods as well. Although she noted the presence of secondary tells lying to the west and north of the high mound, 59 she was unable to visit them. Once again, there is a remarkable discrepancy between the survey and the excavation results.

Tall Brak represents a slightly different case. The northern, highest part of the main tell was occupied during the second millennium BC, including the Mittani period, as revealed by the work of Max Mallowan ${ }^{60}$ and David and Joan Oates. ${ }^{6 I}$ Remains of a palace, a small temple, and a number of houses were excavated there, indicating that the site was relatively important during the Mittani period. Yet, the area covered by the Mittani settlement (about 5 hectares) is just a fraction of the entire tell. However, the Mittani city included another, possibly extensive housing area located to the north of the main tell on the plain. ${ }^{62}$ It seems that the two most important buildings (the temple and the palace) were built on the main tell, probably for ritual or security reasons. Some houses that were located on the summit of the tell probably belonged to people serving the needs of these two structures, but the main housing area was situated in a more comfortable location on the plain.

The Khabur Survey provided further evidence for the transfer of settlements to a location at the bottom of a high mound during the Mittani period. Such a situation was observed at the site Tall Rhazal Tahtani (no. 5I) on the Khabur, where a third millennium mound Io meters high was surrounded by two lower terraces ( $4 \mathrm{~m}$ and $2 \mathrm{~m}$ high respectively) yielding Mittani and later material. Gre Zil Kabir (site no. 54) yielded evidence of an early second millennium BC settlement on the main tell, I8 meters high. Mittani sherds were collected mainly in an area located to the west of the tell and on two low hills located about $200 \mathrm{~m}$ west of the main site. At Tall Qattine (no. 7) the summit of the tell, about $20 \mathrm{~m}$ high, yielded mainly Uruk and third millennium material, while Mittani sherds were collected from a much lower part of the site, at a level of about four to eight meters above the ground.

58 Bieliński 2000; Bieliński 2002.

59 Cf. plan of the site, Lyonnet 2000, fig. 22.

60 Mallowan I947, $78 \mathrm{f}$.

6I Oates et al. I997.

62 Oates I993, I82f. 
However, the situation described above is not common. Many tells on which Mittanian sherds were found are extensive mounds of medium height where sherds were evenly distributed over the whole surface of the tell (sites nos. 28, 34, 37, 45, 60). Several of the larger excavated sites fall into this category as well, for example Tall Barri, Tall Hamidiya, and, to a certain extent, Tall Mozan. One could add Tall Beizari, but the site has not been excavated yet.

Other sites where Mittani pottery was found included a high mound and one or two lower terraces that were occupied simultaneously. Site nos. 4, I4, I7, 24, 25, 27, 29, 30, 3I, $32,38,50$ belong to this category. Some of these sites (nos. 25, 3I, 38, 45) were already settled during the MBA period and it is likely that the topography of these sites resulted from Habur Ware period developments.

Even though the tendency for Mittani period settlements to be located on lower terraces or on the plain in the vicinity of an earlier settlement mound seems to be quite apparent, it will still be necessary to carry out a full survey of the area before the importance of this trend can be evaluated. It is also difficult to speculate on the reasons that lie behind this change. One possible cause could be related to the availability of drinking water. It is easy to imagine that people moved to a less elevated area in order to avoid difficulties related to carrying water uphill, i.e. to a tell already 20 or more meters high. At some of the large sites settlement continued on the highest part of the mound. In these cases it is possible that the location of the settlement was determined by other factors - first of all by the presence of important religious or civil building(s) - i.e. temples or palaces. This was clearly the case with Tall Brak, Tall Mozan, Tall Hamidiye, and most likely of Tall Barri, as well.

\subsubsection{The Balikh Valley}

The tendency of settlements in the Upper Khabur to move to lower elevations in the Mittani period cannot be observed in the Balikh Valley survey data presented by Curvers. ${ }^{63}$ Nevertheless, in the case of Tall Abyad (BS-280) Lyon noted the presence of Mittani sherds on the plain, ca. $70 \mathrm{~m}$ from the main mound. ${ }^{64}$ In his opinion, their presence reflected a significant increase in the site area, which would cover not only the tell ( 0.8 ha in area, settlement of medium intensity) but also included a lower city. It is equally possible that they mark the location of a smaller settlement, independent of that on the main mound.

63 Curvers I991.

64 Lyon 2000, I03. 


\subsubsection{The Lower Khabur}

The Lower Khabur area also offers no evidence for the tendency observed in the Upper Khabur area. It is possible that this can be explained with the need to control and protect already existing, larger settlements in the area.

\subsection{The transfer of local centers within a regional network}

\subsubsection{The Upper Khabur}

The Khabur Survey did not reveal any potential urban centers from the earlier part of the second millennium BC in the Upper Khabur area. However, excavations show that during that time a number of large and certainly important settlements existed either within the region or on the border of the surveyed area (Tall Chagar Bazar, Tall Ailun, Tall Barri, Tall Brak and Tall Mozan). They constituted an important part of the settlement system. Cuneiform texts from Tall Chagar Bazar, but also from sites located outside the Khabur Triangle (Mari, Leilan, Kültepe) offer some information on the role of these settlements. It is clear that the Old Assyrian trade road to Anatolia crossed the area, probably running from Apum (likely Tall Muhammad Diyab) due west, to avoid the control of large urban centers located at Tall Mozan in the north and Tall Brak in the south. The tentative identification of Tall Arbid with Amaz, recently proposed by Jesper Eidem, ${ }^{65}$ supports this reconstruction. Correspondence from the Mari archives and evidence from Tall Chagar Bazar ${ }^{66}$ demonstrate that relatively small sites may have played a significant role in the administration of this area, especially when the regional political centers were located outside the surveyed area.

The number of large sites dating to the latter part of the second millennium in the surveyed area is again extremely small. As in the previous period, larger sites are located on the border of the survey area; besides the already mentioned tells of Brak, Barri, and Mozan, some new large towns appear during this period: Tall Fakhariya, Tall Hasake, and Tall Hamidiye. At least two of these sites (Tall Fakhariya/Waššukanni and Tall Hamidye/Taidum) seem to have enjoyed, at least for some time, the position of capital cities of the Mittani state. The location of the above mentioned large sites is most likely determined by the presence of perennial rivers: the Khabur and the Jaghjagh. Only Tall Mozan does not fit into this pattern, but its location close to the mountains suggests that there were more favorable environmental conditions there.

During the Middle Assyrian period two tendencies can be observed. Again, no cities are present within the survey area; all the sites that are known to date are of a small size,

65 Eidem 2008, 40.

66 Talon I997; Tunca - Baghdo 2008. 
most of them bearing in fact only traces of settlement. Cities, as before, are either on the Khabur or on the Jaghjagh. Some of them (Brak, Hamidiye) have limited Middle Assyrian occupation that is visible, in fact, only in the public buildings of the preceding period. This phenomenon indicates that the Assyrians maintained the administrative functions of these older buildings. Other cities (Fakhariya, Barri) seem to flourish under the new rule.

\subsubsection{The Balikh Valley}

As was already mentioned, the Balikh Valley survey revealed a significant continuity in the distribution and size of local centers throughout most of the second millennium BC.

During the Middle Bronze Age local centers can be identified both in the Balikh Valley and outside of it. Local centers outside the Balikh Valley still influenced the area under scrutiny. Tall Bi'a/Tuttul is a good example of such a site. Located in the Euphrates Valley, close to the Balikh-Euphrates confluence, it clearly exercised economic and political dominance over at least the southernmost part of the Balikh Valley. This influence is illustrated by an Old Babylonian text from Mari (TH.72.I) that mentions herds of cattle dispatched to the Balikh Valley for grazing. ${ }^{67}$ Texts from Tuttul provide evidence for at least four settlements located most likely in the Balikh valley: Şerda and Ahuna, located relatively close to Tuttul, and Šubat-Šamaš and Zalpa (tentatively identified with Tall Hammam at-Turkman), further upstream. The area controlled by Tuttul was divided into two provinces: the southern one, administered directly from Tuttul, and the northern one, with a seat in the city of SubatŠamaš. ${ }^{68}$

This situation corresponds to the one documented by the Balikh survey. Two clusters of sites are apparent in the southern part of the valley. Tall Seman (BS-83), on the western bank, and BS-84, located on the opposite side of the river, about $30 \mathrm{~km}$ north of Tall Bi'a as the crow flies, together formed a center of one such cluster (aggregate area of I7-I9 ha), which controlled the only larger agricultural plain in the southern part of the valley. Yet, it is impossible to safely identify Tall Seman either with Șerda or with Šubat-Šamaš. The second cluster is located further north, at a Balikh - Wadi Isa confluence and includes two equally ranking sites: Tall Khadriya (BS-I39) and Tall Sabaniyeh (BS-II7), whose aggregate area is about is ha.

The more densely settled northern part of the valley had five clusters of cites, which controlled shorter sections of the valley. These clusters were located around Tall Hammam at-Turkman (BS-I75), Tall Jittal (BS-2II), Tall Sahlan (BS-247), Tall Breri (BS-297) and Tall Abyad (BS-280). Of these, only Tall Sahlan is considerably larger (ca. I6 ha); other tells cover an area of ca. 5-6 hectares. However, one has to take into account the presence of Har-

67 Birot $1973,2$.

68 Krebernik 200I, I2f. 
ran, only $45 \mathrm{~km}$ north of Tall Hammam. It is possible that its zone of influence covered the northernmost part of the Balikh drainage.

All the above-mentioned centers continue to exist and play the same role in the settlement pattern during the Mittani period. The only remarkable change is a reduction in area of the largest sites (for instance Tall Bi'a from 25 to II ha, Tall Sahlan from i6 to 8.3 ha, etc.). Yet, the analysis of interactions between sites reveals that the network of the settlements remains unaltered. ${ }^{69}$

It is remarkable that pairs of settlements lying on the opposite banks of the Balikh (one is Tall Seman, and the other BS-84) cease to exist in the latter part of the second millennium; only Tall Sahlan continues to be intensively settled. As settlements located in such places are often considered to indicate river crossings, this phenomenon may be explained in two different ways. Either the Balikh was easier to cross during the latter part of the second millennium BC, or trade roads shifted and earlier river crossings lost their significance.

Drastic changes took place during the Middle Assyrian period. Most of the earlier settlements, which had been occupied throughout the earlier part of the second millennium BC, were abandoned. Some excavated sites even show evidence of conflagration. Middle Assyrian settlements were then established, possibly after a short break, using some of the points occupied before. Yet, these settlements seem to be smaller than before. Finally, only one cluster of sites could be plotted on the map for this period, in the vicinity of Tall Sabi Abyad. This situation is probably a reflection of an administrative attempt to control and to exploit the central area of the valley. Cuneiform texts discovered at Tall Sabi Abyad, Tall Fakhariya and Tall Šeh Hamad inform us that a dunnu (fortified settlement) which was created at Tall Sabi Abyad was entrusted to a side branch of the royal family, whose members used to bear titles "the grand vizier" and "the king of Hanigalbat" and whose holdings included several villages located in the vicinity of the dunnu. ${ }^{\circ}$

\subsubsection{The Lower Khabur Valley}

While the Middle Bronze period settlements in the Lower Habur Valley are relatively numerous (I7 sites out of 33 settlements during the second millennium) a considerable number of these sites yielded a very limited number of sherds of the MBA date. A significant feature is that the presence of the MBA period is confirmed on all large sites, and on four of them (Tall Šeh Hamad, Tall Ašamsani, Tall Fadgami and Tall Taban) occupation continues throughout the second millennium BC. The number of sites located on the western bank of the river is only slightly lower than that of sites on the eastern bank. This was al-

69 Lyon 2000, I5.

70 Wiggermann 2000, I7I-185. 
ready the case during the Mittani period, when $44 \%$ of sites were located on the western bank, while the remaining $56 \%$ were on the eastern one..$^{7 \mathrm{~T}}$ This indicates, in my opinion, that the Khabur Valley region was located in the core area of the state during the Mittanian period. The situation changed radically at the beginning of the Middle Assyrian period, when nearly all large settlements are located on the eastern side of the river (Šeh Hamad, Tunenir, Taban, Fadgami and Hasake), with the exception of Tall Agaga..$^{2}$ The same distribution can be observed for smaller sites: $78 \%$ of small sites dated to the Middle Assyrian period are located on the eastern bank of the river. The reason for this distribution must be related to the organization of the Assyrian state, whose center of political and administrative authority was located in the east, in the Tigris valley. Another reason for the location of most settlements on the "Assyrian" bank is possible antagonism towards Mittani-Hanigalbat, located in the west.

\section{Conclusions}

A review of the results of the surveys carried out in three areas of northern Mesopotamia reveals that in each of them settlement patterns developed differently during the second millennium BC.73

The Khabur Triangle exhibited a relatively modest occupation during the Middle Bronze Age, especially in the western part of the area. This situation changed in the Mittani period, when both the number and the size of the settlements increased significantly. These observations are in contrast to results from other surveys that were carried out in the central and eastern part of northern Mesopotamia. In the Tall Leilan Survey a very high number of Middle Bronze Age sites (157) were discovered,74 while for the latter part of the second millennium the number of sites dropped to about $25 \%$ of this number.75 The North Jazireh survey also shows a noticeable drop in the number of mid to late second millennium sites. ${ }^{6}$ During the Middle Bronze Age the number of settlements remains stable and one can observe a considerable degree of continuity. By contrast, the intensity of occupation of the settlements changes from the Mittani to the Middle Assyrian period: only four Middle Assyrian sites were described as very intensively or intensively used, in contrast to 30 sites of the Mittani period. This drop in intensity of occupation may reflect a depopulation of the area.

7I Morandi Bonacossi 2008, I93.

72 Morandi Bonacossi 2008, I9I.

73 A similar conclusion on development of settlement in the third and early second millennium BC was reached by Wossink 2009, I00, Fig. 5.I4.

74 Ristvet 2005 .

75 Rova, pers. comm.

76 Wilkinson - Tucker I995, 59f.; Wossink 2009, 8I-85. 86-88, Figs. 5.9f., offered a different interpretation of the situation in the North Jazireh Survey, suggesting a slow, but constant growth of settlement at least through the third and early second millennium BC. 
The Balikh Drainage area showed a gradual drop in settlement density. Density peaked in the middle part of the MBA during the mid to late second millennium, affecting at first the southern part of the area. Yet, the settlement pattern of the Middle Bronze and Mittani period did not differ. Drastic changes appear during the Middle Assyrian period, when most of the older settlements were abandoned and a new, very limited network was reconstructed in the vicinity of Tall Sabi Abyad. While there were some small cities present in the Balikh Valley during the Middle Bronze, some of which were probably used as capital cities for small political entities, they lost their importance during the Late Bronze Age and shrank in size in favor of a large urban center located most likely in Harran.

The Khabur valley settlement consisted of a number of larger sites, most of which were occupied continuously during the second millennium BC. Thus, the changes in the settlement pattern concern mainly the number and the distribution of small sites. Their number increased during the Mittani period, and dropped radically in the subsequent period, when settlement was limited to urban sites only. These radical changes of the settlement pattern took place both at the beginning and at the end of the Mittani period.

Finally, two general observations may be added. The first one concerns the reliability of interpretations of field survey results. The Balikh Drainage Survey is a clear illustration of this problem. The same area which was studied by two different scholars (Curvers and Lyon) yielded quite different results. This situation may be to some extent related to a greater knowledge of second millennium BC pottery in northern Mesopotamia, in particular pottery of the latter part of the millennium. This allowed Lyon to re-evaluate some of the results of Curver's fieldwork. On the other hand, one has the impression that some of the results of the original study by Curvers are based on a misinterpretation of sources, for example, the division of the Mittani period material into two phases and of the MBA period into three phases, as well as mechanical estimations of site areas (for instance o.I ha when I sherd was identified).

The other remark, of a more general nature, concerns the already mentioned observation that each of the analyzed regions developed different settlement patterns during the second millennium BC. We have to leave it to historians to look for political, economic, social, or environmental reasons which could explain such a situation. For archaeologists studying settlement patterns in the Near East it is more important to understand that there is no single, uniform pattern of development or change throughout northern Mesopotamia. Consequently, each region has to be analyzed on its own, and only when such an analysis is concluded can its results be compared to other results in order to obtain a more general picture. 


\title{
Bibliography
}

Akkermans 1993

P. M. M. G. Akkermans, Villages in the Steppe: Later Neolithic Settlement and Subsistence in the Balikh Valley, Northern Syria (Ann Arbor 1993).

\begin{abstract}
Akkermans 2006
P. M. M. G. Akkermans, The Fortress of Ilī-pāda. Middle Assyrian Architecture at Tell Sabi Abyad, Syria, in: P. Butterlin - M. Lebeau - J.-Y. Monchambert - J. L. Montero Fenollos B. Muller (eds.), Les èspaces syro-mésopotamiques. Dimensions de l'expérience humaine au Proche-Orient ancien. Volume d'hommage offert à Jean-Claude Margueron, Subartu I7, (Turnhout 2006) 20I-2II.
\end{abstract}

Akkermans et al. 1992

P. M. M. G. Akkermans, On the Frontier of Assyria: Excavations at Tell Sabi Abyad, Akkadica $84-85$, I992, I-52.

\section{Anastasio 2007}

S. Anastasio, Das Obere Habur-Tal in der Jazira zwischen dem I3. und 5. Jh. v. Chr. Die Keramik des Projektes „Prospection archéologique du Haut-Khabour (Syrie du N.-E.)“ (Firenze 2007).

\section{Bartl 1990}

K. Bartl, Khirbet esh-Shenef: A Late Bronze Settlement in the Balikh Valley, Akkadica 67, I990, I0-32.

\section{Bernbeck 1994}

R. Bernbeck, Steppe als Kulturlandschaft, BBVO - Ausgrabungen I (Berlin I994).

\section{Bieliński 2000}

P. Bieliński, Tell Arbid, the Fourth Season, Polish Archaeology in the Mediterranean Vol. XI, Reports I999, 273-284.

\section{Bieliński 2002}

P. Bieliński, Tell Arbid, the Sixth Campaign of Excavations. Preliminary Report, Polish Archaeology in the Mediterranean Vol. XIII, Reports 200I, 279-294.

\section{Birot 1973}

M. Birot, Nouvelles découvertes épigraphiques au palais royal de Mari (salle II5), Syria 50, I973, I-II.

\section{Bretschneider 1997}

J. Bretschneider, Die Unterstadt (Feld J), in: M. Lebeau - A. Suleiman (eds.), Tell Beydar, Three Seasons of Excavations (I992-I994): A Preliminary Report (Turnhout 1997) 209-230.

\section{Córdoba 1988}

J. M. Córdoba, Prospección en valle de rió Balih (Syria). Informe provisional, Aula Orientalis 6/2, I988, I49-I88.

\section{Eidem 2008}

J. Eidem, Old Assyrian Trade in northern Syria. The Evidence from Tell Leilan, in: J.G. Dercksen (ed.), Anatolia and the Jazira during the Old Assyrian Period, PIHANS CXI (Istanbul 2008) 3I-4I. 
Eidem - Warburton 1996

J. Eidem - D. Warburton, In the Land of Nagar: A survey around Tell Brak, Iraq 57, I996, 5I-64.

\section{Ergenzinger - Kühne I99I}

PJ. Ergenzinger - H. Kühne, Ein regionales Bewässerungssystem am Habur, in: H. Kühne (ed.), Die rezente Umwelt von Tall Seh Hamad und Daten zur Umweltrekonstruktion der assyrischen Stadt Dur Katlimmu, BATSH I (Berlin I99I) I63-I90.

\section{Faivre 1999}

X. Faivre, Histoire du peuplement du „Triangle du Habur“ au Bronze Moyen et au début du Bronze récent: étude céramologique d'après les fouilles de Tell Mohammed Diyab (I987-1996) et la prospection dans le bassin occidental du Haut Habur (I989-I997), unp. PhD thesis, Université Charles de Gaulle, Lille, I999.

\section{Hole 1997}

F. Hole, Evidence for Mid-Holocene Environmental Degradation in the Western Habur Drainage, NE Syria, in: H. Nüzhet Dalfes - G. Kukla - H. Weiss (eds.), Third Millennium BC Climate Change and Old World Collapse, Proceedings of the NATO Advanced Research Workshop on Third Millennium BC Climate Change and Old World Collapse, held at Kemer, Turkey, September 19-24, I994, NATO Advanced Studies Institute Series I: Global Environmental Change, vol. 49 (Berlin I997) 39- 66.

\section{Krebernik 200I}

M. Krebernik, Die altorientalische Schriftfunde. Ausgrabungen in Tell Bi'a/Tuttul - II, WVDOG vol. Io० (Saarbrücken 200I).

\section{Kühne $1978 / 79$}

H. Kühne, Zur historischen Geographie am Unteren Hābūr. Zweiter, vorläufiger Bericht über eine archäologische Geländebegehung; in: AfO 26, I978/79, I8I-I95.

\section{Kühne - Röllig I980}

H. Kühne - W. Röllig, The Lower Habur. A Preliminary Report on a Survey conducted by the Tübinger Atlas des Vorderen Orients in 1975; in: Les Annales Archéologiques Arabes Syriennes 27/28, I980, II5-I40.

\section{Kühne - Röllig 1983}

H. Kühne - W. Röllig, The Lower Habur. Second Preliminary Report on a Survey in I977; in: AAS 33:2, I983, I87-I99.

\section{Kulemann-Ossen 2009}

S. Kulemann-Ossen, Zum Siedlungsgeschehen des 2. Jahrtausends v. Chr. am Unteren Habur, in: E. Cancik-Kirschbaum - N. Ziegler (eds.), Entre les fleuves - I. Untersuchungen zur historischen Geographie Obermesopotamiens im 2. Jahrtausend, Berlin 2009, I5I-I63.

\section{van Loon 1988}

M. N. van Loon, Hammam et-Turkman I. Report on the University of Amsterdam's I98I-I984 Excavations in Syria, PIHANS 63 (Istanbul I988).

\section{Lyon 2000}

J. P. Lyon, Middle Assyrian Expansion and Settlement Development in the Syrian Jazira: The View from the Balikh Valley, in: R. Jas (ed.), Rainfall and Agriculture in Northern Mesopotamia, Proceedings of the Third MOS Symposium (Leiden I999), PIHANS LXXXVIII (Istanbul 2000) 89-126. 


\section{Lyonnet 2000}

B. Lyonnet, Prospection archéologique Haut-Khabur Occidental (Syrie du N.E.), vol. I, Bibliothèque Archéologique et Historique, T. 155 (Beyrouth 2000).

\section{Mallowan 1947}

M. E. L. Mallowan, Excavations at Brak and Chagar Bazar, Syria, Iraq 9, I947, I-259.

\section{Meijer 1986}

J. W. Meijer, A Survey in Northeastern Syria, PIHANS vol. LVIII (Istanbul I986).

\section{Monchambert 1984a}

J.-Y. Monchambert, La Futur Lac du Moyen Khabour: Rapport sur la prospection archéologique menée en I983, Syria 6I, I984, I8I-2I8.

\section{Monchambert $1984 \mathrm{~b}$}

J.-Y. Monchambert, Prospection archéologique sur l'emplacement du futur lac du Moyen Khabour, Akkadica 39, septembre/octobre I984, I-7.

\section{Morandi Bonacossi 1996}

D. Morandi Bonacossi, Tra il fiume e la steppa. Insediamento e uso del territorio nella bassa valle del fiume Habur in epoca neo-assira, HANE Monographs I (Padova I996).

\section{Morandi Bonacossi 2008}

D. Morandi Bonacossi, Betrachtungen zur Siedlungs- und Bevölkerungsgeschichte des unteren Habur-Gebietes in der neuassyrischen Zeit, in: H. Kühne (ed.), Umwelt und Subsitenz der assyrischen Stadt Dur-Katlimmu am unteren Habur (Wiesbaden 2008) I89-210.

\section{Oates - Oates 1993}

D. Oates - J. Oates, Excavations at Tell Brak I992-93, Iraq 55, I993, I55-I99.

\section{Oates et al. 1997}

D. Oates - J. Oates - H. McDonald, Excavations at Tell Brak. Vol. I: The Mitanni and Old Babylonian Periods (Cambridge I997).

\section{Postgate 1973}

J. N. Postgate, Harran, RlA 4, I973, I22-I25.

\section{Pruss 1990}

A. Pruss, Cities in the Steppe: Results of the Wadi Hamar Survey, a Lecture Given at 46th RAI, Paris, on July IIth, 2000.

\section{Ristvet 2005}

L. Ristvet, Settlement, Economy, and Society in the Tell Leilan Region, Syria, 3000-1000 B.C., unp. PhD thesis, University of Cambridge (Mass.), 2005.

\section{Talon 1997}

Ph. Talon, Old Babylonian Texts from Chagar Bazar, Akkadica Supplementum X (Brussels I997).

\section{Tunca - Baghdo 2008}

Ö. Tunca - A. el-Massih Baghdo, Chagar Bazar (Syrie) III. Les trouvailles épigraphiques et sigillographiques du Chantier I (2000-2002) (Louvain 2008). 
Ur 2004

J. A. Ur, Urbanism and Socitey in the Third Millennium UpperHabur Basin, unp. PhD thesis, University of Chicago, 2004.

\section{Wiggermann 2000}

F. A. M. Wiggermann, Agriculture in the Northern Balikh Valley. The Case of Middle Assyrian Tell Sabi Abyad, in: R. Jas (ed.), Rainfall and Agriculture in Northern Mesopotamia, Proceedings of the Third MOS Symposium (Leiden I999), PIHANS LXXXVIII (Istanbul 2000) I7I-23I.

\section{Wilkinson 1996}

T. J. Wilkinson, Sabi Abyad: The Geoarchaeology of a Complex Landscape, in: P.P.M.G. Akkermans (ed.), Tell Sabi Abyad. The Late Neolithic Settlement I (Leiden I996) I-24.

\section{Wilkinson 1998}

T. J. Wilkinson, Water and Human Settlement in the Balikh Valley, Syria: Investigations from I992-I995, JFieldA 25/1, I998, 63-88.

\section{Wilkinson 2000a}

T. J. Wilkinson, Regional Approaches to Mesopotamian Archaeology: The Contribution of Archaeological Surveys, Journal of Archaeological Research 8/3, 2000, 217-267.

\section{Wilkinson 200ob}

T. J. Wilkinson, Archaeological Survey of the Tell Beydar Region, Syria 1997, in: K. van Lerberghe - G. Voet (eds.), Tell Beydar, Environmental and Technical Studies, Subartu VI (Turnhout 2000) I-36.

\section{Wilkinson - Tucker 1995}

T. J. Wilkinson - D. J. Tucker, Settlement Development in the North Jazira, Iraq. A Study of the Archaeological Landscape, Iraq Archaeological Reports 3 (Warminster 1995).

\section{Wossink 2009}

A. Wossink, Challenging the Climate Change. Competition and Cooperation between the Pastoralists and Agriculturalists in the Northern Mesopotamia (3000-1600 BC) (Leiden 2009). 